\title{
Proanthocyanidin Polymer-Rich Fraction of Stryphnodendron adstringens Promotes in Vitro and in Vivo Cancer Cell Death via Oxidative Stress
}

\author{
Vanessa Kaplum ${ }^{1}$, Anelise C. Ramos', Marcia E. L. Consolaro ${ }^{3}$, Maria A. Fernandez', \\ Tânia Ueda-Nakamura' ${ }^{1}$, Benedito P. Dias-Filho' ${ }^{1}$, Sueli de Oliveira Silva', \\ João C. P. de Mello' and Celso V. Nakamura ${ }^{1 *}$ \\ 1 Programa de Pós-Graduação em Ciências Farmacêuticas, Universidade Estadual de Maringá, Maringá, Brazil, ${ }^{2}$ Programa \\ de Pós-Graduação em Ciências Biológicas, Universidade Estadual de Maringá, Maringá, Brazil, ${ }^{3}$ Programa de \\ Pós-Graduação em Biociências e Fisiopatologia, Universidade Estadual de Maringá, Maringá, Brazil
}

OPEN ACCESS

Edited by:

Ruiwen Zhang,

University of Houston, United States

Reviewed by:

Suzanne Maria Hurst,

The New Zealand Institute for Plant \&

Food Research Ltd., New Zealand

Alexandre Henriques,

Neuro-Sys, France

*Correspondence:

Celso V. Nakamura

cvnakamura@uem.br

Specialty section:

This article was submitted to

Ethnopharmacology,

a section of the journal

Frontiers in Pharmacology

Received: 10 April 2018

Accepted: 08 June 2018

Published: 03 July 2018

Citation:

Kaplum V, Ramos AC

Consolaro MEL, Fernandez MA,

Ueda-Nakamura T, Dias-Filho BP,

Silva SO, de Mello JCP and

Nakamura CV (2018)

Proanthocyanidin Polymer-Rich

Fraction of Stryphnodendron

adstringens Promotes in Vitro and

in Vivo Cancer Cell Death via

Oxidative Stress.

Front. Pharmacol. 9:694.

doi: 10.3389/fphar.2018.00694
Cervical cancer is the fourth most common cancer that affects women, mainly through human papilloma virus (HPV) infection with high-risk HPV16 and HPV18. The present study investigated the in vitro anticancer activity and mechanism of action of a proanthocyanidin polymer-rich fraction of Stryphnodendron adstringens (F2) in cervical cancer cell lines, including HeLa (HPV18-positive), SiHa (HPV16-positive), and C33A (HPV-negative) cells, and also evaluated in vivo anticancer activity. In vitro, cell viability was determined by the MTT assay. Cell migration was determined by the wound healing assay. The mechanism of action was investigated by performing ultrastructural analysis and evaluating reactive oxygen species (ROS) production, mitochondrial metabolism, lipoperoxidation, BCL-2 family expression, caspase expression, and DNA and cell membrane integrity. In vivo activity was evaluated using the murine Ehrlich solid tumor model. F2 time- and dose-dependently reduced cell viability and significantly inhibited the migration of cervical cancer cells. HeLa and SiHa cells treated with F2 $\left(\mathrm{I}_{50}\right)$ exhibited intense oxidative stress (i.e., increase in ROS and decrease in antioxidant species) and mitochondrial damage (i.e., mitochondrial membrane potential depolarization and a reduction of intracellular levels of adenosine triphosphate). Increases in the Bax/BCL-2 ratio and caspase 9 and caspase 3 expression, were observed, with DNA damage that was sufficient to trigger mitochondria-dependent apoptosis. Cell membrane disruption was observed in C33A cells $\left(\mathrm{IC}_{50}\right.$ and $\left.\mathrm{IC}_{90}\right)$ and HeLa and SiHa cells ( $\left.\mathrm{I}_{90}\right)$, indicating progress to late apoptosis/necrosis. The inhibition of ROS production by $\mathrm{N}$-acetylcysteine significantly suppressed oxidative stress in all three cell lines. In vivo, F2 significantly reduced tumor volume and weight of the Ehrlich solid tumor, and significantly increased lipoperoxidation, indicating that F2 also induces oxidative stress in the in vivo model. These findings indicate that the proanthocyanidin polymer-rich fraction of $S$. adstringens may be a potential chemotherapeutic candidate for cancer treatment.

Keywords: proanthocyanidins, cervical cancer cells, oxidative stress, apoptosis, in vivo activity 


\section{INTRODUCTION}

Cervical cancer is the fourth most common cancer that affects women worldwide (Graham, 2017). Human papilloma virus (HPV) infection is predominantly related to cervical cancer. Nearly $70 \%$ of all cases are caused by high-risk HPV16 and HPV18 (Crosbie et al., 2013).

Stryphnodendron adstringens (Mart.) Coville, popularly known as "barbatimão", is typically found in the Brazilian savannah (Albuquerque et al., 2007). Its stem bark has several biological actions, including antimicrobial activity (Ishida et al., 2006; de Freitas et al., 2018), antiprotozoan activity (Holetz et al., 2005) and antiinflammatory effects (Henriques et al., 2016). The genotoxic and acute and chronic toxicity of this plant have been assessed in rodents (Costa et al., 2010, 2013). This plant has been shown to be cytotoxic for human breast cancer cells (Sabino et al., 2017). The proanthocyanidin polymer-rich fraction of $S$. adstringens stem bark is rich in condensed tannins, or proanthocyanidins, including several flavan-3-ols, such as prodelphinidins and prorobinetinidins (de Mello et al., 1996a,b, 1999; Ishida et al., 2006).

Polyphenols, as proanthocyanidins, exhibit dual antioxidant and pro-oxidant activity, thus they are indicated for prevention and treatment of cancer, consequently (León-González et al., 2015). Pro-oxidant activity of polyphenols is generally dependent on concentration and the presence of redox-active metals, resulting in an increase of reactive oxygen species (ROS) (Pizzino et al., 2017). Low ROS levels are necessary for cell growth and proliferation, however, persistently high levels can lead to cellular oxidative injury (Moloney and Cotter, 2017). Loss of equilibrium between ROS and endogenous antioxidant species results in oxidative stress (Sosa et al., 2013). Based on its intensity, oxidative stress can induce cell death, including by apoptosis (Martindale and Holbrook, 2002; Fulda et al., 2010).

Apoptosis results from extrinsic (death receptor) or intrinsic (mitochondrial) pathways. In the extrinsic-dependent pathway, there is an interaction between death receptors and ligands, such as FasL/FasR. In the mitochondria-dependent pathway, disturbances in mitochondrial membrane integrity result from a pore-forming mechanism that is controlled by the BCL-2 family, especially pro-apoptotic Bax and antiapoptotic BCL-2 (Sinha et al., 2013). Pro-apoptotic factors are released into the cytosol resulting in caspase 9 and caspase 3 activation, which can cause diverse cellular damage, such as DNA fragmentation, a hallmark of apoptosis (Prokhorova et al., 2015). Necrosis is characterized by the loss of cell membrane integrity, which may be attributable to intense oxidative stress and mitochondrial damage (Ryter et al., 2007).

The aim of the present study was to investigate the prooxidant properties of a proanthocyanidin polymer-rich fraction of S. adstringens (F2) through the in vitro anticancer activity and mechanism of action in cervical cancer cell lines, including HeLa, $\mathrm{SiHa}$, and $\mathrm{C} 33 \mathrm{~A}$ cells, and also to evaluate in vivo anticancer activity in a murine Ehrlich solid tumor model.

\section{MATERIALS AND METHODS}

\section{Chemicals}

The following chemicals were used: fetal bovine serum (FBS); Dulbecco's Modified Eagle Medium (DMEM; Gibco Invitrogen); carbonylcyanide m-chlorophenylhydrazone (CCCP); 3-[4,5dimethylthiazol-2-yl]-2,5- diphenyltetrazolium bromide (MTT); dichlorodihydrofluorescein diacetate $\left(\mathrm{H}_{2} \mathrm{DCFDA}\right)$; Amplex Red Hydrogen Peroxide/Peroxidase Assay Kit; 5,5-dithiobis-(2-nitrobenzoic acid) (DTNB); tetramethylrhodamine ethyl ester (TMRE); Cell Titer-Glo Luminescent Cell Viability Assay; Hoechst 33342; diphenyl-1-pyrenylphosphine (DPPP); dimethylsulfoxide (DMSO); ethylenediaminetetraacetic acid (EDTA); $\mathrm{N}$-acetylcysteine (NAC); sodium dodecyl sulfate (SDS) and propidium iodide (PI).

\section{Preparation of Proanthocyanidin Polymer-Rich Fraction}

Stem bark from S. adstringens was collected in São Jerônimo da Serra, Paraná, Brazil, in March 2014. A voucher specimen was deposited at the herbarium of Universidade Estadual de Maringá (HUEM 28197). The bark was dried in an incubator and pulverized. A crude extract of the bark was obtained by turbo extraction in acetone:water (7:3) as described by Ishida et al. (2006). The crude extract was then filtered in a Buchner filter, and the organic solvent was removed by rotavapor and lyophilized. The proanthocyanidin polymer-rich fraction (F2) was obtained by partitioning the crude extract in water:ethyl acetate $(500 \mathrm{ml} ; 1: 1)$.

\section{Cell Lines and Cell Culture}

The HeLa (HPV18-positive), SiHa (HPV16-positive), and C33A (HPV-negative) cervical cancer cell lines and human immortalized keratinocytes (HaCaT) were provided by Dr. Luiza L. Villa (ICESP, School of Medicine, University of São Paulo/Brazil) and Dr. Silvya S. Maria-Engler (Faculty of Pharmaceutical Sciences, University of São Paulo/Brazil). The cells were maintained at $37^{\circ} \mathrm{C}$ under a $5 \% \mathrm{CO}_{2}$ atmosphere in DMEM supplemented with $10 \%$ heat-inactivated FBS and antibiotics (50 U/ml penicillin and $50 \mathrm{mg} / \mathrm{ml}$ streptomycin).

\section{Cell Viability Assay}

Cell viability was determined by the MTT assay. HeLa, SiHa, $\mathrm{C} 33 \mathrm{~A}$ and $\mathrm{HaCaT}$ cells were plated at a density of $2.5 \times 10^{5}$ cells $/ \mathrm{ml}$ in a 96-well cell culture plate for $24 \mathrm{~h}$ at $37^{\circ} \mathrm{C}$ under a $5 \% \mathrm{CO}_{2}$ atmosphere. The cells were treated with the proanthocyanidin polymer-rich fraction $(1,10,25,50$, and $100 \mu \mathrm{g} / \mathrm{ml}$ ) for 24 and $48 \mathrm{~h}$ at $37^{\circ} \mathrm{C}$ under a $5 \% \mathrm{CO}_{2}$ atmosphere. The cells were then washed in phosphate-buffered saline (PBS), and MTT ( $50 \mu \mathrm{l}, 2 \mathrm{mg} / \mathrm{ml}$ ) was added, followed by incubation for $4 \mathrm{~h}$ at $37^{\circ} \mathrm{C}$. Formazan crystals were solubilized in DMSO, and absorbance was read at $570 \mathrm{~nm}$ in a microplate reader (BioTek Power Wave XS spectrophotometer). The concentration that inhibited absorbance in 50 and $90 \%$ of the cells $\left(\mathrm{IC}_{50}\right.$ or $\mathrm{IC}_{90}$, respectively) compared with the untreated control was determined by non-linear regression analysis. 


\section{Morphology of Cervical Cancer Cell Lines}

$\mathrm{HeLa}$, SiHa, and C33A cells were plated at a density of $2.5 \times 10^{5}$ cells $/ \mathrm{ml}$ in a 24 -well cell culture plate for $24 \mathrm{~h}$ at $37^{\circ} \mathrm{C}$ under a $5 \%$ $\mathrm{CO}_{2}$ atmosphere. The cells were pre-incubated with or without $\mathrm{N}$-acetylcysteine (5 mM) for $2 \mathrm{~h}$. Afterward, the cells were treated with the proanthocyanidin polymer-rich fraction $\left(\mathrm{IC}_{50}\right.$ and $\mathrm{IC}_{90}$ according to cell line) for $24 \mathrm{~h}$. Cell morphology was observed under a phase-contrast inverted microscope (Olympus CKX41; $40 \times$ magnification).

\section{Cervical Cancer Cell Lines Wound Healing Assay}

The wound healing assay evaluates cellular migration in vitro. $\mathrm{HeLa}, \mathrm{SiHa}$, and C33A cells were plated at a density of $2.5 \times 10^{5}$ cells $/ \mathrm{ml}$ in a 24-well cell culture plate for $24 \mathrm{~h}$ at $37^{\circ} \mathrm{C}$ under a $5 \% \mathrm{CO}_{2}$ atmosphere. The cells were incubated with $0.5 \%$ heat-inactivated FBS for $6 \mathrm{~h}$. The cells were scratched with a sterile $200 \mu \mathrm{l}$ pipette tip, washed with PBS, and treated with the proanthocyanidin polymer-rich fraction $\left(\mathrm{F} 2 ; \mathrm{IC}_{50}\right.$ and $\mathrm{IC}_{90}$ according to cell line) for $24 \mathrm{~h}$ at $37^{\circ} \mathrm{C}$ under a $5 \% \mathrm{CO}_{2}$ atmosphere. Cell migration was observed under a phase-contrast inverted microscope (Olympus CKX41; $5 \times$ magnification).

\section{Transmission Electron Microscopy of Cervical Cancer}

$\mathrm{HeLa}, \mathrm{SiHa}$, and C33A cells were plated at a density of $2.5 \times 10^{5}$ cells $/ \mathrm{ml}$ for $24 \mathrm{~h}$ at $37^{\circ} \mathrm{C}$ under a $5 \% \mathrm{CO}_{2}$ atmosphere. The cells were pre-incubated with or without $N$-acetylcysteine $(5 \mathrm{mM})$ for $2 \mathrm{~h}$. The cells were treated with the proanthocyanidin polymerrich fraction ( $\mathrm{IC}_{50}$ and $\mathrm{IC}_{90}$ according to cell line) for $24 \mathrm{~h}$. The cells were washed with PBS and fixed with $2.5 \%$ glutaraldehyde in $0.1 \mathrm{M}$ sodium cacodylate buffer ( $\mathrm{pH} 7.4$ ) at $25^{\circ} \mathrm{C}$ for $2 \mathrm{~h}$. The cells were postfixed with $1 \%$ osmium tetroxide and $0.8 \%$ potassium ferricyanide for $60 \mathrm{~min}$ at room temperature while protected from light, washed with $0.1 \mathrm{M}$ sodium cacodylate buffer, and dehydrated in increasing concentrations of acetone. The material was embedded in increasing concentrations of Epon resin and polymerized at $60^{\circ} \mathrm{C}$ for $72 \mathrm{~h}$. Thin sections were contrasted with uranyl acetate and lead citrate and observed in a JEOL JEM 1400 transmission electron microscope.

\section{Analysis of Cell Death by Acridine Orange and Propidium lodide Double Staining}

Cell death was analyzed by acridine orange (AO) and propidium iodide (PI) double staining. HeLa, SiHa, and C33A cells were plated at a density of $2.5 \times 10^{5}$ cells $/ \mathrm{ml}$ in coverslips for $24 \mathrm{~h}$ at $37^{\circ} \mathrm{C}$ under a $5 \% \mathrm{CO}_{2}$ atmosphere. The cells were pre-incubated with or without $\mathrm{N}$-acetylcysteine $(5 \mathrm{mM})$ for $2 \mathrm{~h}$. The cells were treated with the proanthocyanidin polymer-rich fraction $\left(\mathrm{IC}_{50}\right.$ and $\mathrm{IC}_{90}$ according to cell line) for $24 \mathrm{~h}$. The cells were washed with PBS and marked with AO $(10 \mu \mathrm{g} / \mathrm{ml})$ and PI $(4 \mu \mathrm{g} / \mathrm{ml})$ for $15 \mathrm{~min}$ in the dark. Fluorescent staining was analyzed using an Olympus BX51 fluorescence microscope, and images were captured using a UC30 camera within $30 \mathrm{~min}$. The criteria of identification were the following: viable cells have a green nucleus and intact structure; early apoptosis appears as a bright-green nucleus with chromatin condensation; late apoptosis appears as dense orange areas of chromatin condensation; and secondary necrosis appears as a reddish-orange nucleus. The number of viable cells, early apoptotic cells, late apoptotic cells and secondary necrotic cells were determined in 200 cells, counted in triplicate.

\section{Reactive Oxygen Species Production in Cervical Cancer Cell Lines}

The production of ROS was detected by marker $\mathrm{H}_{2}$ DCFDA. HeLa, SiHa, and C33A cells were plated at a density of $2.5 \times 10^{5}$ cells $/ \mathrm{ml}$ for $24 \mathrm{~h}$ at $37^{\circ} \mathrm{C}$ under a $5 \% \mathrm{CO}_{2}$ atmosphere. The cells were pre-incubated with or without $\mathrm{N}$-acetylcysteine $(5 \mathrm{mM})$ for $2 \mathrm{~h}$. Afterward, the cells were treated with the proanthocyanidin polymer-rich fraction ( $\mathrm{IC}_{50}$ and $\mathrm{IC}_{90}$ according to cell line) for $24 \mathrm{~h}$. The positive control was $\mathrm{H}_{2} \mathrm{O}_{2}(200 \mu \mathrm{M})$. The cells were washed with PBS, marked with $10 \mu \mathrm{M} \mathrm{H}_{2}$ DCFDA for $30 \mathrm{~min}$ in the dark, detached by trypsinization, and resuspended in PBS. The fluorescence intensity was quantified using a fluorescence microplate reader (VICTOR X3, PerkinElmer) at excitation and emission wavelengths of 488 and $530 \mathrm{~nm}$, respectively. The fluorescence intensity was normalized to the number of cells (Souza et al., 2017).

\section{Hydrogen Peroxide Production in Cervical Cancer Cell Lines}

The production of $\mathrm{H}_{2} \mathrm{O}_{2}$ was detected by Amplex RED reagent. $\mathrm{HeLa}, \mathrm{SiHa}$, and C33A cells were plated at a density of $2.5 \times 10^{5}$ cells $/ \mathrm{ml}$ for $24 \mathrm{~h}$ at $37^{\circ} \mathrm{C}$ under a $5 \% \mathrm{CO}_{2}$ atmosphere. The cells were pre-incubated with or without $\mathrm{N}$-acetylcysteine $(5 \mathrm{mM})$ for $2 \mathrm{~h}$. Afterward, the cells were treated with the proanthocyanidin polymer-rich fraction $\left(\mathrm{IC}_{50}\right.$ and $\mathrm{IC}_{90}$ according to cell line) for $24 \mathrm{~h}$. The positive control was $\mathrm{H}_{2} \mathrm{O}_{2}(200 \mu \mathrm{M})$. The cells were washed with PBS, detached by trypsinization, resuspended in PBS, and marked with $12 \mu \mathrm{M}$ Amplex RED and $0.05 \mathrm{UI} / \mathrm{ml}$ horseradish peroxidase. The fluorescence intensity was quantified using a fluorescence microplate reader (VICTOR $\mathrm{X}$, PerkinElmer) at excitation, and emission wavelengths of 530 and $590 \mathrm{~nm}$, respectively. The fluorescence intensity was normalized to the number of cells (Souza et al., 2017).

\section{Reduced Thiol Levels in Cervical Cancer Cell Lines}

Reduced thiol levels were detected by DTNB reagent. HeLa, $\mathrm{SiHa}$, and $\mathrm{C} 33 \mathrm{~A}$ cells were plated at a density of $2.5 \times 10^{5}$ cells $/ \mathrm{ml}$ for $24 \mathrm{~h}$ at $37^{\circ} \mathrm{C}$ under a $5 \% \mathrm{CO}_{2}$ atmosphere. The cells were pre-incubated with or without $\mathrm{N}$-acetylcysteine $(5 \mathrm{mM})$ for $2 \mathrm{~h}$. Afterward, the cells were treated with the proanthocyanidin polymer-rich fraction ( $\mathrm{IC}_{50}$ and $\mathrm{IC}_{90}$ according to cell line) for $24 \mathrm{~h}$. The positive control was $\mathrm{H}_{2} \mathrm{O}_{2}(200 \mu \mathrm{M})$. The cells were washed with PBS. Tris-HCl buffer (10 mM; pH 2.5) was added and sonicated. Cellular debris was removed by centrifugation. Afterward, $100 \mu \mathrm{l}$ of the supernatant, $100 \mu \mathrm{l}$ of phosphate buffer 
(500 mM; pH 7.5), and $20 \mu \mathrm{l}$ of DTNB (1 mM) were placed in each microtiter well. Absorbance was read at $412 \mathrm{~nm}$ in a microplate reader (BioTek Power Wave XS spectrophotometer).

\section{Mitochondrial Membrane Potential and DNA Integrity Assay in Cervical Cancer Cell Lines}

The mitochondrial membrane potential $(\Delta \Psi \mathrm{m})$ was detected by the marker TMRE. HeLa, SiHa, and C33A cells were plated at a density of $2.5 \times 10^{5}$ cells $/ \mathrm{ml}$ in 24 plates with or without coverslips for $24 \mathrm{~h}$ at $37^{\circ} \mathrm{C}$ under a $5 \% \mathrm{CO}_{2}$ atmosphere. The cells were pre-incubated with or without $N$-acetylcysteine $(5 \mathrm{mM})$ for $2 \mathrm{~h}$. Afterward, the cells were treated with the proanthocyanidin polymer-rich fraction ( $\mathrm{IC}_{50}$ and $\mathrm{IC}_{90}$ according to cell line) for $24 \mathrm{~h}$. The positive control was CCCP $(100 \mu \mathrm{M})$. The cells were washed with PBS, detached by trypsinization, resuspended in PBS, and marked with TMRE (25 nM) for 30 min in the dark at $37^{\circ} \mathrm{C}$ under a $5 \% \mathrm{CO}_{2}$ atmosphere. The fluorescence intensity was quantified using a fluorescence microplate reader (VICTOR X3, PerkinElmer) at excitation and emission wavelengths of 540 and $595 \mathrm{~nm}$, respectively. In another experiment, the cells were marked with TMRE (25 nM) and Hoechst $33342(10 \mu \mathrm{g} / \mathrm{ml})$ for $30 \mathrm{~min}$ in the dark. Fluorescent staining was analyzed using an Olympus BX51 fluorescence microscope, and images were captured using a UC30 camera.

\section{Intracellular ATP Determination in Cervical Cancer Cell Lines}

Intracellular adenosine triphosphate (ATP) levels were detected by Cell Titer-Glo reagent. HeLa, SiHa, and C33A cells were plated at a density of $2.5 \times 10^{5}$ cells $/ \mathrm{ml}$ for $24 \mathrm{~h}$ at $37^{\circ} \mathrm{C}$ under a $5 \% \mathrm{CO}_{2}$ atmosphere. The cells were pre-incubated with or without $N$-acetylcysteine ( $5 \mathrm{mM}$ ) for $2 \mathrm{~h}$. Afterward, the cells were treated with the proanthocyanidin polymer-rich fraction $\left(\mathrm{IC}_{50}\right.$ and $\mathrm{IC}_{90}$ according to cell line) for $24 \mathrm{~h}$. The positive control was KCN $(1000 \mu \mathrm{M})$. The cells were washed with PBS, detached by trypsinization, resuspended in PBS, and marked with Cell TiterGlo reagent for $10 \mathrm{~min}$ at room temperature. The luminescence intensity was quantified using a fluorescence microplate reader (VICTOR X3, PerkinElmer).

\section{Real-Time Polymerase Chain Reaction in Cervical Cancer Cell Lines}

HeLa, SiHa, and C33A cells were plated at a density of $2.5 \times 10^{5}$ cells $/ \mathrm{ml}$ in cell culture flasks for $24 \mathrm{~h}$ at $37^{\circ} \mathrm{C}$ under a $5 \% \mathrm{CO}_{2}$ atmosphere. The cells were pre-incubated with or without $N$-acetylcysteine $(5 \mathrm{mM})$ for $2 \mathrm{~h}$. Afterward, the cells were treated with the proanthocyanidin polymerrich fraction ( $\mathrm{IC}_{50}$ and $\mathrm{IC}_{90}$ according to cell line) for $12 \mathrm{~h}$. The cells were washed with PBS. RNA was extracted by the phenol-chloroform method and treated with amplification grade DNase I (Invitrogen) to remove genomic DNA contamination. Complementary DNA (cDNA) was synthesized from $1 \mu \mathrm{g}$ of total RNA with iScript cDNA synthesis kit (Bio-Rad) using the thermal cycler (Mastercycler, Eppendorf). Real time PCR was performed with SYBR Green PCR Master Mix (Applied Byosystems) on the LightCycler 96 System (Roche Applied Science). The analysis of PCR products was performed using LightCycler 96 software (Roche Applied Science). All of the procedures were performed according to the manufacturer's instructions. The following primer sequences were researched in the GenBank Nucleotide Database: Bax (F: 5'-TTTGCTTCAGGGTTTCATCC-3' and R: 5'-CAGTTGAAGTTGCCGTCAGA-3'); BCL-2 (F: 5'-GCAGGC GACGAGTTTGAACT-3' and R: 5'-GTGTCTGGTCATTTC CGACTGA-3'); Caspase 3 (F: 5' -ATACTCCACAGCACCTGGT TAT- $3^{\prime}$ and R: 5'-AATGAGAGGGAAATACAGTACCAA-3'); Caspase 9 (F: 5'-GTACGTTGAGACCCTGGACGAC-3' and R: 5'-GCTGCTAAGAGCCTGTCTGTCACT-3') and 18S rRNA gene (F: 5'-GTAACCCGTTGAACCCCATT-3' and R: 5' -CCA TCCAATCGGTAGTAGCG- $\left.3^{\prime}\right)$. The amplification conditions were $95^{\circ} \mathrm{C}$ pre-denaturation for $10 \mathrm{~min}$, followed by 40 cycles at $95^{\circ} \mathrm{C}$ for $15 \mathrm{~s}$ and $60^{\circ} \mathrm{C}$ for $60 \mathrm{~s}$. The expression levels of each sample were normalized to the housekeeping $18 \mathrm{~S}$ rRNA gene according to the $\Delta \mathrm{Ct}$ formula $\left(\mathrm{Ct}_{\text {target gene }}-\mathrm{Ct}_{18 \mathrm{SrRNA}}\right)$. Relative mRNA expression levels were calculated using the $2^{-\Delta \Delta C t}$ relative quantitative method, where $\Delta \Delta \mathrm{Ct}$ values were calculated based on $\Delta \mathrm{Ct}$ treated cells $-\Delta \mathrm{Ct}$ control cells (Schmittgen and Livak, 2008).

\section{DNA Fragmentation Revealed by Gel Electrophoresis in Cervical Cancer Cell Lines}

HeLa, SiHa, and C33A cells were plated at a density of $2.5 \times 10^{5}$ cells $/ \mathrm{ml}$ for $24 \mathrm{~h}$ at $37^{\circ} \mathrm{C}$ under a $5 \% \mathrm{CO}_{2}$ atmosphere. The cells were pre-incubated with or without $N$-acetylcysteine $(5 \mathrm{mM})$ for $2 \mathrm{~h}$. Afterward, the cells were treated with the proanthocyanidin polymer-rich fraction ( $\mathrm{IC}_{50}$ and $\mathrm{IC}_{90}$ according to cell line) for $24 \mathrm{~h}$. The cells were washed with PBS and lysed in a solution that contained Tris- $\mathrm{HCl}(10 \mathrm{mM}$ : $\mathrm{pH}$ 8.0), EDTA (1 $\mathrm{mM}), \mathrm{NaCl}(100 \mathrm{mM})$, SDS $(0.5 \%)$, and proteinase $\mathrm{K}$ $(20 \mathrm{mg} / \mathrm{ml})$ at $65^{\circ} \mathrm{C}$ for $15 \mathrm{~min}$. RNAse $(1 \mathrm{mg} / \mathrm{ml})$ was added and incubated at $37^{\circ} \mathrm{C}$ for $15 \mathrm{~min}$. DNA was extracted by the phenol:chloroform:isoamyl alcohol method (25:24:1; v/v). DNA electrophoresis was performed on $1.0 \%$ agarose gel in Tris/boric acid buffer at $90 \mathrm{~V}$ for $1 \mathrm{~h}$, and DNA was stained with SYBR safe DNA gel stain (Invitrogen). The molecular weight marker was the 100 bp DNA Ladder. Images were obtained using In vivo MS FX PRO (Carestream Molecular Imaging, Carestream Health).

\section{Lipid Peroxidation in Cervical Cancer Cell Lines}

Lipid peroxidation was detected by the marker DPPP. HeLa, $\mathrm{SiHa}$, and $\mathrm{C} 33 \mathrm{~A}$ cells were plated at a density of $2.5 \times 10^{5}$ cells $/ \mathrm{ml}$ for $24 \mathrm{~h}$ at $37^{\circ} \mathrm{C}$ under a $5 \% \mathrm{CO}_{2}$ atmosphere. The cells were pre-incubated with or without $N$-acetylcysteine $(5 \mathrm{mM})$ for $2 \mathrm{~h}$. Afterward, the cells were treated with the proanthocyanidin polymer-rich fraction ( $\mathrm{IC}_{50}$ and $\mathrm{IC}_{90}$ according to cell line) for $24 \mathrm{~h}$. The positive control was $\mathrm{H}_{2} \mathrm{O}_{2}(200 \mu \mathrm{M})$. The cells were washed with PBS, detached by trypsinization, resuspended in PBS, and marked with DPPP $(50 \mu \mathrm{m})$ for $15 \mathrm{~min}$ at room temperature. The fluorescence intensity was quantified using a fluorescence microplate reader (VICTOR X3, PerkinElmer) 
at excitation and emission wavelengths of 351 and $460 \mathrm{~nm}$, respectively. The fluorescence intensity was normalized to the number of cells (Souza et al., 2017).

\section{Cell Membrane Integrity Assay in Cervical Cancer Cell Lines}

Cell membrane integrity was detected by the marker PI. HeLa, $\mathrm{SiHa}$, and C33A cells were plated at a density of $2.5 \times 10^{5}$ cells $/ \mathrm{ml}$ for $24 \mathrm{~h}$ at $37^{\circ} \mathrm{C}$ under a $5 \% \mathrm{CO}_{2}$ atmosphere. The cells were pre-incubated with or without $N$-acetylcysteine $(5 \mathrm{mM})$ for $2 \mathrm{~h}$. Afterward, the cells were treated with proanthocyanidin polymerrich fraction $\left(\mathrm{IC}_{50}\right.$ and $\mathrm{IC}_{90}$ according to cell line) for $24 \mathrm{~h}$. The positive control was digitonin $(80 \mu \mathrm{M})$. The cells were washed with PBS, detached by trypsinization, resuspended in PBS, and marked with PI $(4 \mu \mathrm{g} / \mathrm{ml})$ for $5 \mathrm{~min}$ at room temperature. The fluorescence intensity was quantified using a fluorescence microplate reader (VICTOR X3, PerkinElmer) at excitation and emission wavelengths of 480 and $580 \mathrm{~nm}$, respectively. The fluorescence intensity was normalized to the number of cells (Souza et al., 2017).

\section{In Vivo Antitumor Activity}

Male BALB/c mice (20-25 g), 4-6 weeks of age, were obtained from Universidade Estadual de Maringá. The animals were maintained at a controlled room temperature $\left(22^{\circ} \mathrm{C} \pm 2{ }^{\circ} \mathrm{C}\right)$ under a $12 \mathrm{~h} / 12 \mathrm{~h}$ light/dark cycle. Food and water were available ad libitum. The Institutional Ethics Committee of Universidade Estadual de Maringá approved all of the procedures in this study (protocol no. 4534200417/2017).

Ehrlich ascites carcinoma (EAC) cells $\left(1 \times 10^{7}\right.$ cells $\left./ \mathrm{ml}\right)$ were injected subcutaneously in the right flanks in male BALB/c mice to obtain the Ehrlich solid tumors. After 15 days, when a palpable mass developed, the animals were randomly separated in two groups ( $n=5 /$ group): control group (treated with PBS vehicle) and proanthocyanidin polymer-rich fraction group (150 mg/kg/day in PBS). The treatment was administered orally by gavage and daily for 28 days. Stock solutions of F2 were prepared daily in PBS. The dimensions of Ehrlich solid tumors were measured weekly with a digital caliper (DIGIMESS ${ }^{\circledR}$ $150 \mathrm{~mm}$ ). The Ehrlich solid tumor volume (TV) was calculated by the following formula: $T V\left(\mathrm{~mm}^{3}\right)=0.52 \times A(\mathrm{~mm}) \times\left[B(\mathrm{~mm})^{2}\right]$, where $A$ and $B$ are the largest and smallest diameters, respectively. On day 28 of treatment, the animals were euthanized, and the solid tumor were excised and weighed.

\section{Lipid Peroxidation in Solid Tumor}

Lipid peroxidation was detected by the thiobarbituric acidreactive substances (TBARS) in terms of malondialdehyde (MDA). After euthanasia, solid tumors were weighed, sonicated, and centrifugated. The supernatant was heated in a solution that contained $0.37 \%$ thiobarbituric acid, $15 \%$ trichloroacetic acid, and $0.25 \mathrm{~N} \mathrm{HCl}$ for $45 \mathrm{~min}$ at $95^{\circ} \mathrm{C}$. Absorbance was read at $532 \mathrm{~nm}$ in a microplate reader (BioTek Power Wave XS spectrophotometer). Then, TBARS concentration was measured based on $\varepsilon$ value of $153,000 \mathrm{M}^{-1} \mathrm{~cm}^{-1}$.

\section{Statistical Analysis}

The data that are presented in the tables and graphs are expressed as the mean \pm standard deviation of at least three independent experiments. The data were analyzed using one- or two-way analysis of variance (ANOVA) followed by Dunnett's or Bonferroni's post hoc test. Values of $p \leq 0.05$ were considered statistically significant. The statistical analysis was performed using Prism 5 software (GraphPad, San Diego, CA, United States).

\section{RESULTS}

\section{Cytotoxic Activity in Cervical Cancer Cell Lines}

The proanthocyanidin polymer-rich fraction exerted time- and dose-dependent cytotoxic activity in the HeLa (HPV18-positive), $\mathrm{SiHa}$ (HPV16-posititve), and C33A (HPV-negative) cervical cancer cell lines (Figures 1A-C). The $\mathrm{IC}_{50}$ for $\mathrm{HeLa}, \mathrm{SiHa}$, and C33A cells was 20.0, 35.4, and $33.5 \mu \mathrm{g} / \mathrm{ml}$ after $24 \mathrm{~h}$ and $15.3,21.3$, and $15.6 \mu \mathrm{g} / \mathrm{ml}$ after $48 \mathrm{~h}$ of treatment, respectively (Figure 1D). After $24 \mathrm{~h}$ of treatment, the $\mathrm{IC}_{90}$ for HeLa, SiHa, and C33A cells was 64.6, 56.1, and $51.8 \mu \mathrm{g} / \mathrm{ml}$, respectively. For human immortalized keratinocytes (HaCaT), the $\mathrm{IC}_{50}$ was 55.4 and $48.1 \mu \mathrm{g} / \mathrm{ml}$ at 24 and $48 \mathrm{~h}$, respectively (Figure 1D). Thus, the cytotoxic activity of F2 was significantly higher in HeLa, SiHa, and C33A cells than in normal cells (HaCaT cells).

The morphology of HeLa, SiHa, and C33A cells treated with F2 was observed under a phase-contrast inverted microscope. All of the cell lines treated with the $\mathrm{IC}_{50}$ of F2 presented alterations in morphology (Figure 1E). Notable alterations of morphology were observed in cells treated with the $\mathrm{IC}_{90}$ of $\mathrm{F} 2$, including irregularity of shape, cellular detachment, and a bright circle around the nucleus. Cells pre-incubated with $\mathrm{N}$-acetylcysteine (NAC) for $2 \mathrm{~h}$ before treatment with F2 ( $\mathrm{IC}_{50}$ and $\left.\mathrm{IC}_{90}\right)$ presented the preservation of morphology, although an increase in cytoplasmic vacuolization was observed.

Cell migration was analyzed by the wound-healing assay. HeLa, SiHa, and C33A cells treated with F2 ( $\mathrm{IC}_{50}$ and $\left.\mathrm{IC}_{90}\right)$ presented significant inhibitions of cell migration compared with the control (Figure 2). For HeLa, SiHa, and C33A cells, the percentage of cell migration in control (untreated) cells was $30.6,64.3$, and $84.1 \%$, respectively. In cells treated with F2, cell migration was less than $10 \%$ for all cell lines (Figure 2).

\section{Transmission Electron Microscopy of Cervical Cancer Cell Lines}

Treatment with F2 $\left(\mathrm{IC}_{50}\right)$ resulted in ultrastructural alterations in HeLa cells, mitochondrial swelling, and an increase in autolysosomes (Figure 3B). Similar alterations were observed in $\mathrm{SiHa}$ cells, with the additional loss of mitochondrial cristae (Figure 3E). HeLa and $\mathrm{SiHa}$ cells treated with the $\mathrm{IC}_{90}$ of $\mathrm{F} 2$ exhibited cell membrane disruption and nuclear membrane alterations (Figures 3C,F, respectively). 


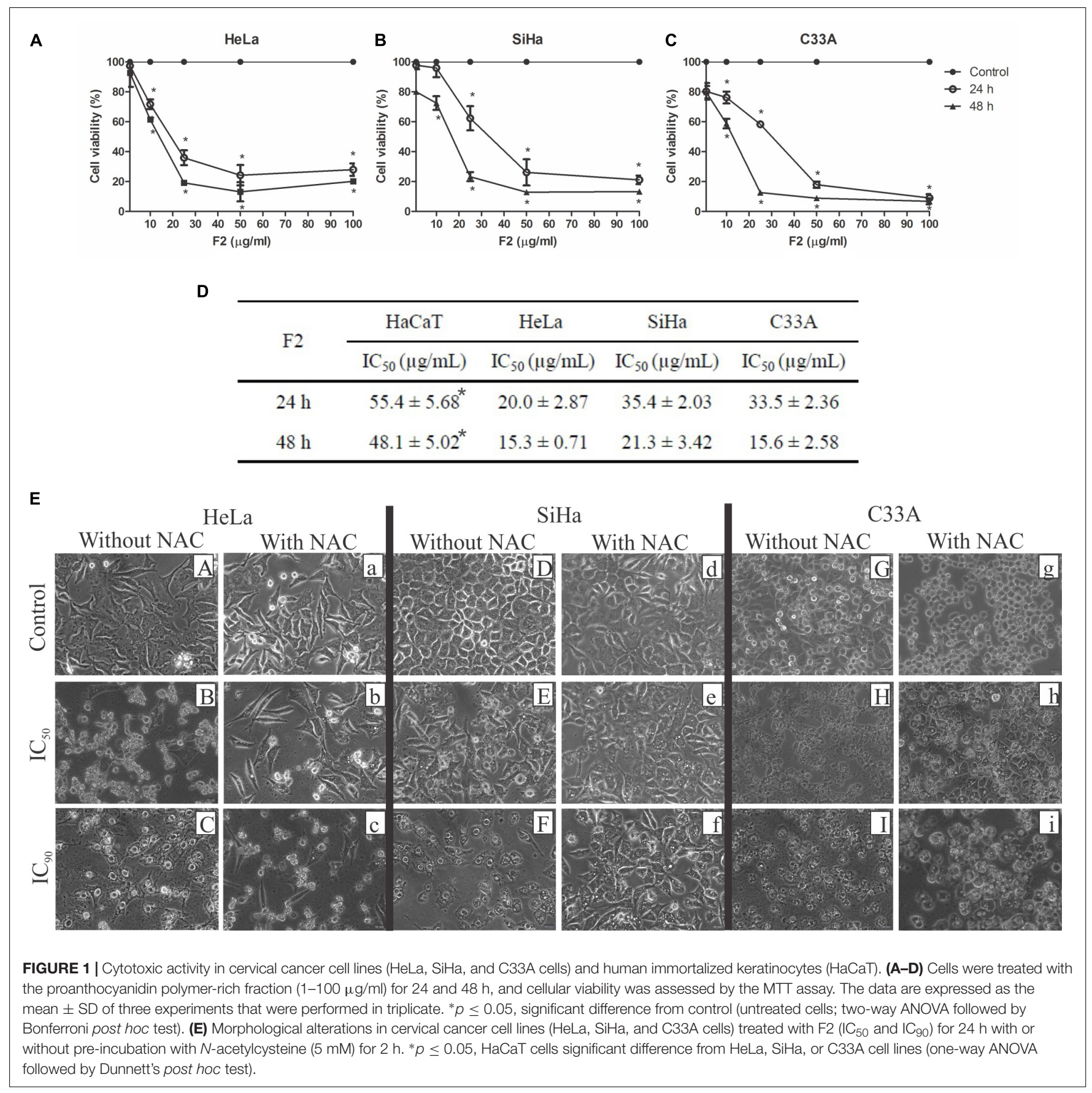

C33A cells treated with the $\mathrm{IC}_{50}$ or $\mathrm{IC}_{90}$ of $\mathrm{F} 2$ exhibited mitochondrial swelling, a loss of mitochondrial cristae, cell membrane disruption, and nuclear membrane alterations (Figures 3H,I, respectively). Cells pre-incubated with NAC for $2 \mathrm{~h}$ before treatment with the $\mathrm{IC}_{50}$ of $\mathrm{F} 2$ exhibited preservation of the ultrastructure of mitochondria, the cell membrane, the nuclear membrane, and autolysosomes (Figures $\mathbf{3 b}, \mathbf{e}, \mathbf{h})$. Treatment with the $\mathrm{IC}_{90}$ of F2 after preincubation with NAC resulted in mitochondrial swelling, a loss of mitochondrial cristae, and an increase in the number and size of autolysosomes (Figures $\mathbf{3 c}, \mathbf{f}, \mathbf{i}$ ). The control groups of HeLa,
SiHa, and C33A cells presented no ultrastructural alterations (Figures 3A,a,D,d,G,g).

\section{Analysis of Cell Death by Acridine Orange and Propidium lodide Double Staining}

The quantification of apoptotic and necrotic cells was performed by acridine orange and propidium iodide double staining, in which viable cells have a green nucleus with an intact structure, early apoptosis cells appears as a bright-green nucleus with 


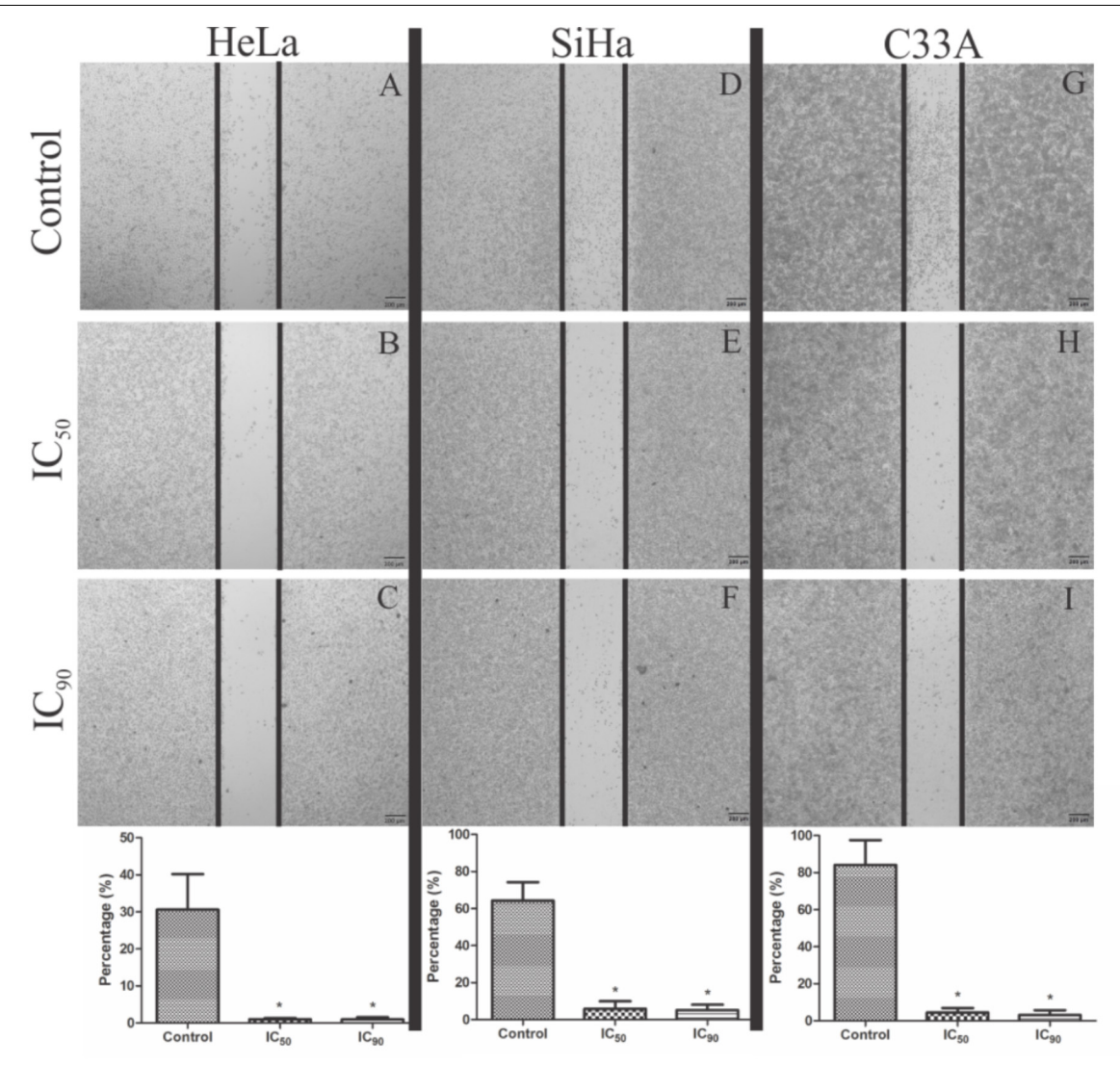

FIGURE 2 | Analysis of cell migration by wound healing assay in cervical cancer cell lines (HeLa, SiHa, and C33A cells). (A,D,G) Control cells (untreated cells). $\mathbf{( B , C , E , F , H , I ) ~ C e l l s ~ t r e a t e d ~ w i t h ~ t h e ~ p r o a n t h o c y a n i d i n ~ p o l y m e r - r i c h ~ f r a c t i o n ~}\left(\mathrm{IC}_{50}\right.$ or $\left.\mathrm{IC}_{90}\right)$ for $24 \mathrm{~h}$ and observed under a phase-contrast inverted microscope. The data are expressed as a percentage of wound closure $\pm \mathrm{SD}$ in three experiments for $\mathrm{HeLa}$, SiHa, and C33A, respectively. * $p \leq 0.05$, significant difference from control (untreated cells; one-way ANOVA followed by Dunnett's post hoc test).

chromatin condensation, late apoptosis appears as dense orange areas with chromatin condensation, and secondary necrosis appears as a reddish-orange nucleus ( $\mathrm{Ng}$ et al., 2013; Hajrezaie et al., 2015).

All of the cell lines treated with $\mathrm{F} 2 \quad\left(\mathrm{IC}_{50}\right.$ or $\mathrm{IC}_{90}$ ) exhibited a significant reduction of viable cells (Figure 4). After treatment with the $\mathrm{IC}_{50}$ of F2, HeLa and SiHa cells exhibited an increase in the percentage of early apoptosis (50.6 and $44.2 \%$, respectively), late apoptosis (23 and 33\%, respectively), and secondary necrosis (27 and 22.8\%, respectively). Preincubation with NAC maintained approximately $50 \%$ of viable cells for both cell lines. After treatment with the $\mathrm{IC}_{90}$, an increase in the percentage of late apoptosis (43 and $51.3 \%$, respectively) and secondary necrosis (42 and 27.3\%, respectively) was observed in $\mathrm{HeLa}$ and $\mathrm{SiHa}$ cells. HeLa and $\mathrm{SiHa}$ cells pre-incubated with NAC and treated with the $\mathrm{IC}_{90}$ had 12 and $10 \%$ secondary necrosis, respectively (Figure 4).

After treatment with the $\mathrm{IC}_{50}$ or $\mathrm{IC}_{90}$ of $\mathrm{F} 2, \mathrm{C} 33 \mathrm{~A}$ cells exhibited an increase in the percentage of late apoptosis (43.5 and 23\%, respectively) and secondary necrosis (37.6 and $77 \%$, respectively). Cells pre-incubated with NAC and treated with the $\mathrm{IC}_{50}$ and $\mathrm{IC}_{90}$ had 56.6 and $18.5 \%$ viable cells and 2.3 and $21 \%$ secondary necrosis, respectively (Figure 4).

\section{Reactive Oxygen Species Production and Reduced Thiols Levels in Cervical Cancer Cell Lines}

The production of ROS in cervical cancer cell lines was analyzed by the marker $\mathrm{H}_{2} \mathrm{DCFDA}$, which is cleaved by esterases and oxidized by ROS into highly green-fluorescent $2^{\prime}, 7^{\prime}$-dichlorofluorescein (DCF) (Yazdani, 2015). HeLa and SiHa cells exhibited a significant increase in ROS production after treatment with the $\mathrm{IC}_{50}$ (434 and $307 \%$, respectively) and $\mathrm{IC}_{90}$ (1,628 and 564\%, respectively; Figure 5A). Cells pre-incubated with the antioxidant NAC exhibited a decrease in the production of ROS after treatment with the $\mathrm{IC}_{50}$ and $\mathrm{IC}_{90}$. Similarly, C33A cells exhibited an increase in ROS production when treated the $\mathrm{IC}_{90}$ of F2 $(1,623 \%)$, and pre-incubation with NAC prevented ROS production. The positive control, $\mathrm{H}_{2} \mathrm{O}_{2}$, increased ROS production.

The production of a specific type of ROS, hydrogen peroxide $\left(\mathrm{H}_{2} \mathrm{O}_{2}\right)$, was analyzed by the marker Amplex Red; which is catalyzed by horseradish peroxidase (HRP) to produce 


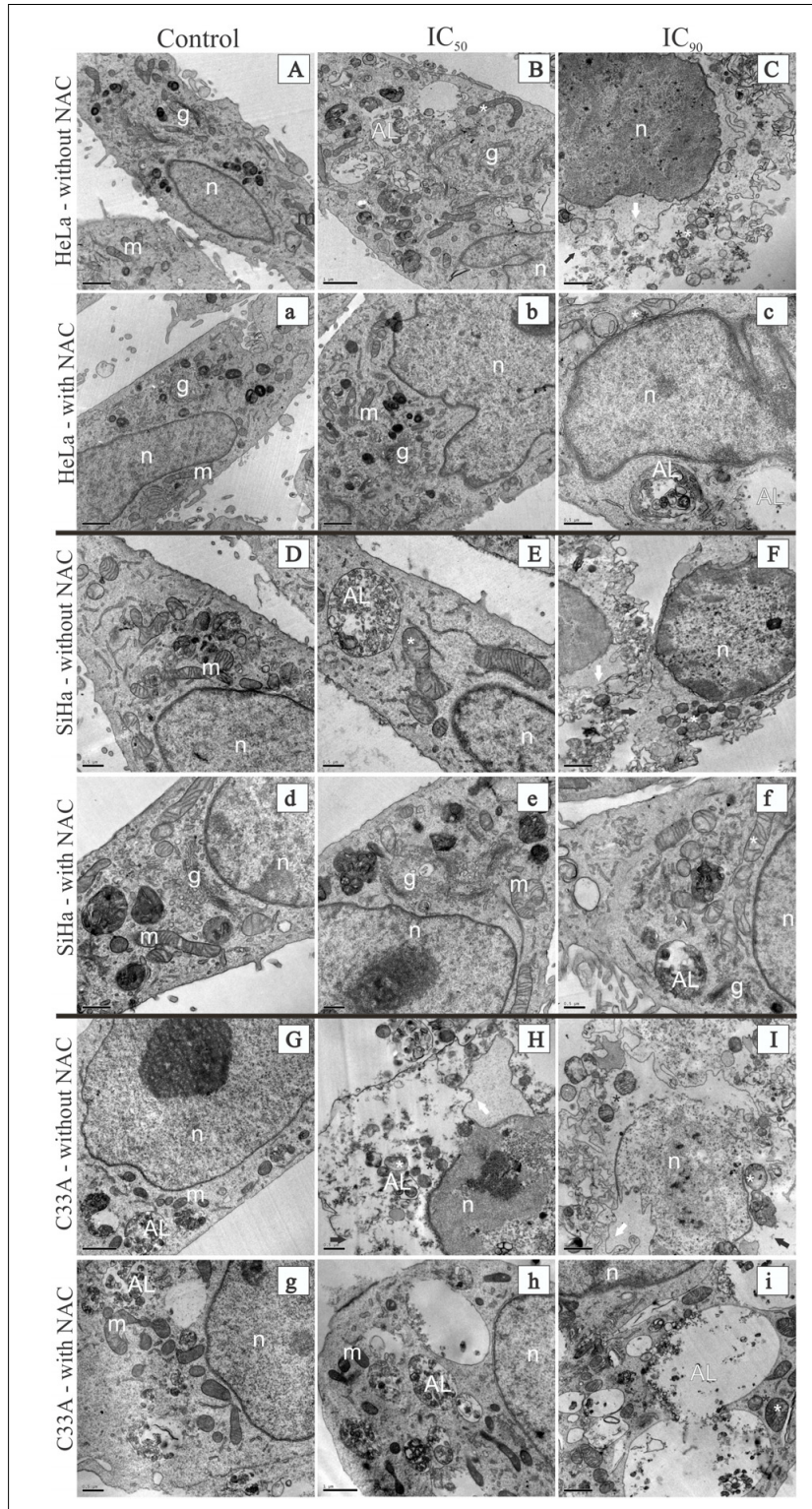

FIGURE 3 | Transmission electron microscopy of cervical cancer cell lines (HeLa, SiHa, and C33A cells) treated with the proanthocyanidin polymer-rich fraction $\left(\mathrm{IC}_{50}\right.$ or $\left.\mathrm{IC}_{90}\right)$ for $24 \mathrm{~h}$. The cells were pre-incubated without (A-I) or with (a-i) $\mathrm{N}$-acetylcysteine for $2 \mathrm{~h}$ before F2 treatment. HeLa, SiHa, and C33A cell control groups (untreated cells) are represented by $(\mathbf{A}, \mathbf{a}),(\mathbf{D}, \mathbf{d})$, and $(\mathbf{G}, \mathbf{g})$, respectively. HeLa, $\mathrm{SiHa}$, and $\mathrm{C} 33 \mathrm{~A}$ cells treated with the $\mathrm{IC}_{50}$ are represented by $(\mathbf{B}, \mathbf{b}),(\mathbf{E}, \mathbf{e})$, and $(\mathbf{H}, \mathbf{h})$, respectively. $\mathrm{HeLa}, \mathrm{SiHa}$, and $\mathrm{C} 33 \mathrm{~A}$ cells treated

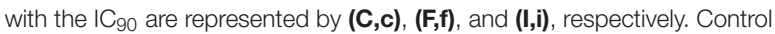
groups (untreated cells) had a normal ultrastructure of organelles. $\mathrm{m}$, mitochondria; g, Golgi apparatus; n, nucleus. HeLa. SiHa, and C33A cells that were treated with the $\mathrm{IC}_{50}$ or $\mathrm{IC}_{90}$ of $\mathrm{F} 2$ presented ultrastructural alterations, including mitochondrial swelling (white asterisk), a loss of mitochondrial cristae (black asterisk), cell membrane disruption (black arrow), nuclear membrane alterations (white arrow), and an autolysosome (AL). Scale bars $=0.5 \mu \mathrm{m}$ in (D,E,H, C-g) and $1 \mu \mathrm{m}$ in (A-C,F,G,I,a,b,h,i).

the highly fluorescent resofurin (Debski et al., 2016). All of the cervical cancer cell lines treated with F2 exhibited an increase in $\mathrm{H}_{2} \mathrm{O}_{2}$ levels (Figure 5B). This effect was observed at a lower intensity in cells pre-incubated with NAC.

Reduced thiol levels were determined using DTNB (Ellman's reagent). This compound uses the GSH-recycling system, where GSSG is progressively reduced to GSH by glutathione reductase and produces a color product 5-thio-2-nitrozenxoic acid, with maximal absorbance at $412 \mathrm{~nm}$ (Chen et al., 2008; Winther and Thorpe, 2014). A significant decrease in reduced thiol levels was observed after treating HeLa, SiHa, and C33A cells with the $\operatorname{IC}_{50}\left(29,65\right.$, and $58 \%$, respectively) and $\operatorname{IC}_{90}(42,66$, and $82 \%$, respectively; Figure 5C). Less of a decrease in reduced thiol levels was observed in cells pre-incubated with NAC, especially in $\mathrm{SiHa}$ and $\mathrm{C} 33 \mathrm{~A}$ cells treated with the $\mathrm{IC}_{50}$ (17 and $20 \%$, respectively) and $\mathrm{IC}_{90}$ (11 and $38 \%$, respectively).

\section{Mitochondrial Membrane Potential and Intracellular ATP Levels in Cervical Cancer Cell Lines}

Considering the ultrastructural alterations of mitochondria in $\mathrm{HeLa}, \mathrm{SiHa}$, and $\mathrm{C} 33 \mathrm{~A}$ cells treated with $\mathrm{F} 2$, we analyzed $\Delta \Psi \mathrm{m}$ using the cationic fluorophore TMRE. This marker accumulates in active mitochondria and emits red fluorescence in polarized mitochondria (Walsh et al., 2017). All of the cells treated with F2 ( $\mathrm{IC}_{50}$ or $\left.\mathrm{IC}_{90}\right)$ exhibited a significant dose-dependent decrease in $\Delta \Psi \mathrm{m}$ compared with the control (untreated cells). $\Delta \Psi \mathrm{m}$ loss was $31.5,46.3$, and $44.4 \%$ in $\mathrm{HeLa}, \mathrm{SiHa}$, and C33A cells that were treated with the $\mathrm{IC}_{50}$ and $49.1,52.7$, and $49.5 \%$ in cells that were treated with the $\mathrm{IC}_{90}$, respectively. The $\Delta \Psi \mathrm{m}$ of cells pre-incubated with NAC underwent less depolarization. The membrane uncoupler CCCP induced the depolarization of $\Delta \Psi \mathrm{m}$ (Figure 6A).

Similar results were observed when $\Delta \Psi$ m was observed under a fluorescence microscope (Figure 6B). Control cells (untreated cells; Figure 6B,A,a,D,d,G,g) exhibited intense red fluorescence, typically found in polarized mitochondria. After treatment with F2 ( $\mathrm{IC}_{50}$ or $\left.\mathrm{IC}_{90}\right)$, red fluorescence significantly decreased. Cells pre-incubated with NAC still presented red fluorescence.

Figure 6C shows intracellular ATP levels, determined by Cell Titer-Glo reagent, in cervical cancer cell lines. A significant decrease in intracellular ATP levels was observed in $\mathrm{HeLa}, \mathrm{SiHa}$, and $\mathrm{C} 33 \mathrm{~A}$ cells treated with the $\mathrm{IC}_{50}(49.7,71.4$, and $73.2 \%$, respectively) and $\mathrm{IC}_{90}(94.4,96.7$, and $84.3 \%$, respectively) of F2. In cells pre-incubated with NAC and treated with the $\mathrm{IC}_{90}$, intracellular ATP levels decreased by $46.2,39.8$, and $53.8 \%$ in HeLa, SiHa, and C33A cells, respectively. The positive control, $\mathrm{KCN}$, decreased luminescence (Figure 6C).

\section{Bax, BCL-2, Caspase 9 and Caspase 3 Expression in Cervical Cancer Cell Lines}

BCL-2 family proteins play an important role in regulating apoptosis as promoters or inhibitors of the cell death process (Hata et al., 2015). Real-time PCR was used to evaluate mRNA expression levels of pro-apoptotic Bax and anti-apoptotic BCL-2. HeLa, SiHa, and C33A cells treated with F2 ( $\mathrm{IC}_{50}$ or $\mathrm{IC}_{90}$ ) exhibited a dose-dependent upregulation of Bax mRNA expression levels (Figure 7A). All of the cell lines exhibited 


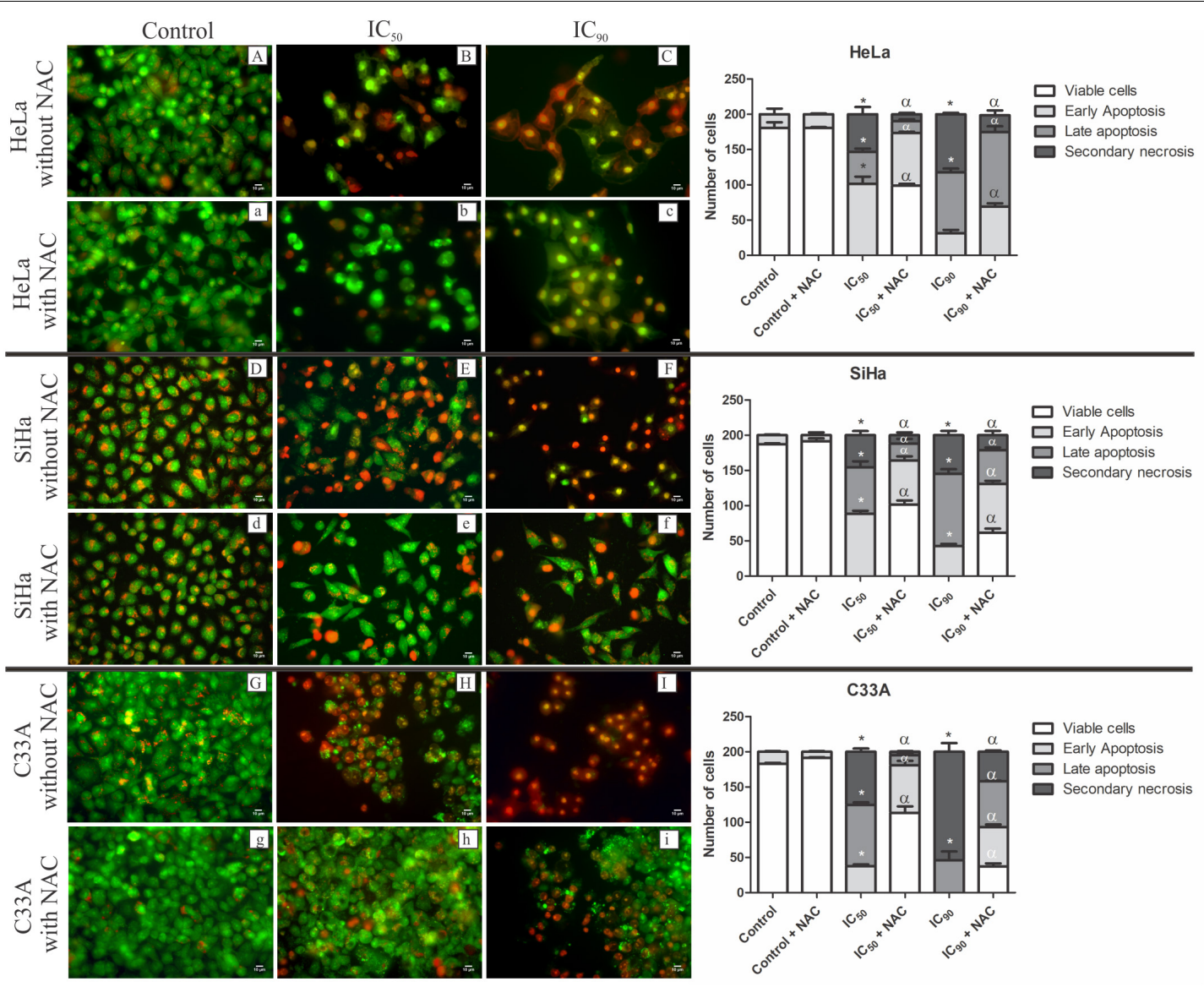

FIGURE 4 | Fluorescence microscopy of cell death by acridine orange and propidium iodide double staining in cervical cancer cell lines (HeLa, SiHa, and C33A cells) treated with the proanthocyanidin polymer-rich fraction $\left(\mathrm{IC}_{50}\right.$ or $\left.\mathrm{IC}_{90}\right)$ for $24 \mathrm{~h}$. The cells were pre-incubated without $(\mathbf{A}-\mathbf{I})$ or with $(\mathbf{a}-\mathbf{i}) \mathrm{N}$-acetylcysteine $(5 \mathrm{mM})$ for $2 \mathrm{~h}$ before F2 treatment. The bars represent the qualitative analysis of fluorescence micrographs determined in 200 cells in triplicate. The following criteria were applied: viable cells (green nucleus with intact structure), early apoptosis (bright-green nucleus with chromatin condensation), late apoptosis (dense orange areas with chromatin condensation), and secondary necrosis (reddish-orange nucleus). ${ }^{*} p \leq 0.05$, significant difference from control (untreated cells; one-way ANOVA followed by Dunnett's post hoc test); ${ }^{\alpha} p \leq 0.05$, significant difference from control + NAC (one-way ANOVA followed by Dunnett's post hoc test).

a dose-dependent downregulation of BCL-2 mRNA expression levels (Figure 7B), consequently increasing the Bax/BCL-2 ratio (Figure 7C). Cells pre-incubated with NAC exhibited less Bax mRNA expression and more BCL-2 mRNA expression, suggesting that $N$-acetylcysteine protected the cells.

The central machinery of the apoptotic cascade involves caspases, such as caspase 9 and caspase 3 (Prokhorova et al., 2015). All of the cell lines treated with F2 for $12 \mathrm{~h}$ exhibited a dose-dependent upregulation of caspase 9 and caspase 3 mRNA expression levels, especially SiHa cells (Figures 8A,B). All of the cell lines pre-incubated with NAC exhibited equal or less caspase 9 and caspase 3 mRNA expression levels compared with cell treated only with F2.

\section{DNA Fragmentation in Cervical Cancer Cell Lines}

Caspases promote DNA fragmentation, a hallmark of apoptosis (Larsen and Sørensen, 2017). DNA fragmentation, determined by agarose gel electrophoresis, was observed in HeLa, SiHa, and
C33A cells after treatment with the $\mathrm{IC}_{50}$ or $\mathrm{IC}_{90}$ of F2 compared with control cells (Figure 9). Similar observations were found with fluorescence microscopy with Hoechst 33342, in which chromatin condensation was also observed (Figure 6B). Cells pre-incubated with NAC exhibited little DNA fragmentation (Figure 9).

\section{Lipoperoxidation and Cell Membrane Integrity in Cervical Cancer Cell Lines}

Lipoperoxidation was analyzed by DPPP marker, which reacts with lipid hydroperoxides to generate fluorescent DPPP oxide (Okimoto et al., 2000). F2 treatment significantly increased lipid peroxidation in $\mathrm{HeLa}, \mathrm{SiHa}$, and $\mathrm{C} 33 \mathrm{~A}$ cells treated with the $\mathrm{IC}_{50}(472,670$, and $840 \%$, respectively) and $\mathrm{IC}_{90}(2,760,1,110$, and $1,360 \%$, respectively). Pre-incubation with NAC resulted in a small increase in lipoperoxidation in cells treated with F2 (Figure 10A). The positive control, $\mathrm{H}_{2} \mathrm{O}_{2}$, increased lipoperoxidation. 


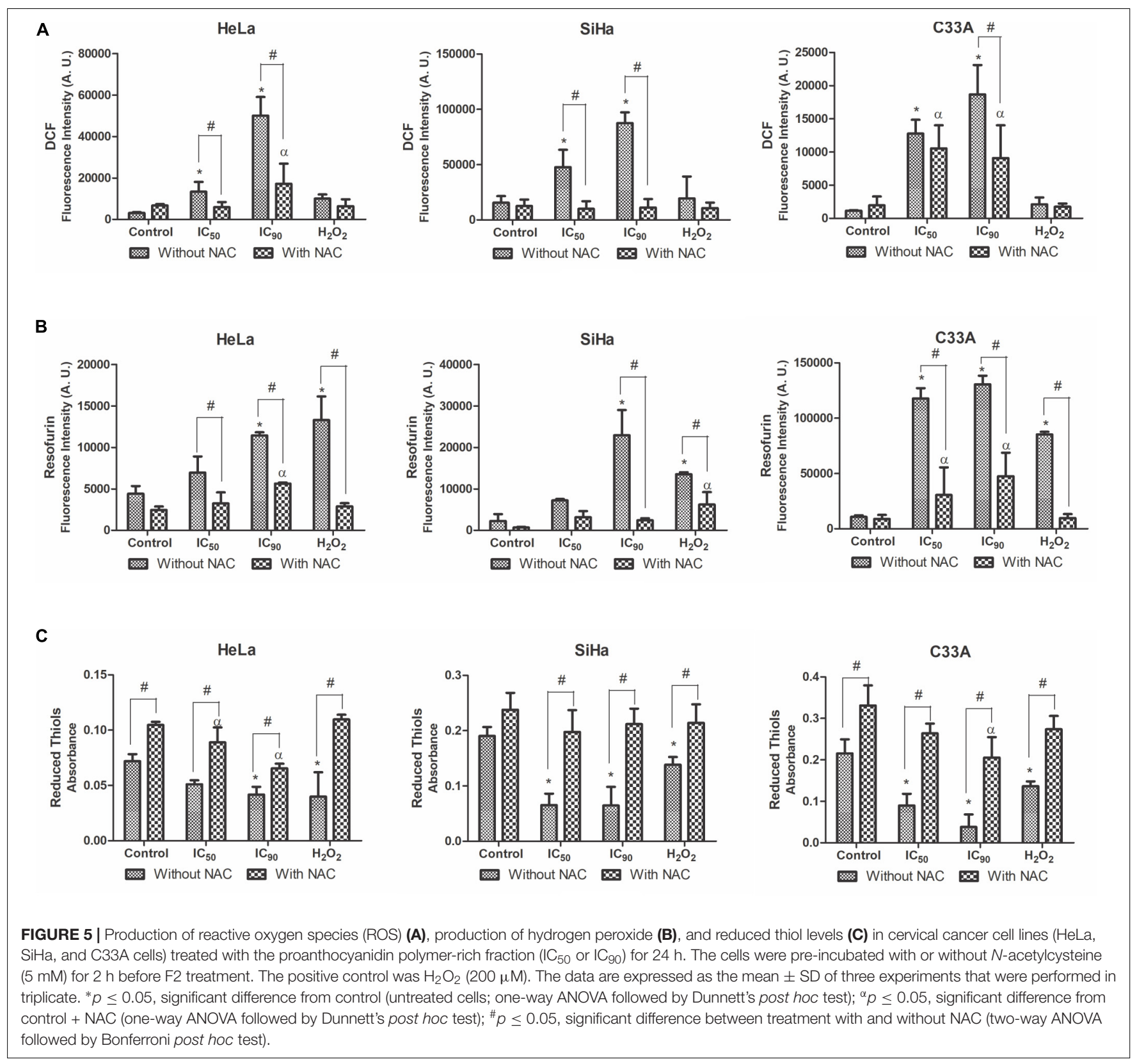

Cell membrane integrity was analyzed by the marker PI. A significant loss of cell membrane integrity was observed in HeLa, SiHa, and C33A cells treated with the $\operatorname{IC}_{50}(413,418$, and $1,540 \%$, respectively) and $\mathrm{IC}_{90}(3,880,1,550$, and $1,700 \%$, respectively) of F2 (Figure 10B). Cells pre-incubated with NAC exhibited less damage to the cell membrane, especially when treated with the $\mathrm{IC}_{50}$. The positive control, digitonin, induced damage to the cell membrane.

\section{In Vivo Antitumor Activity}

In vivo antitumor activity of the proanthocyanidin polymer-rich fraction (F2) was observed in the murine Ehrlich solid tumor model, in which BALB/c mice were treated with $150 \mathrm{mg} / \mathrm{kg} /$ day F2 for 28 days. The dose was selected according to previous acute and chronic toxicity studies in rodents (Costa et al., 2010, 2013). No animals died in neither the control group nor in the F2 group (data not shown). The tumor volume significantly decreased after treatment, with $67.8 \%$ tumor growth inhibition (Figure 11A). F2 significantly reduced tumor weight compared with the control, with a $68.8 \%$ reduction of tumor weight (Figure 11B).

Lipid peroxidation was performed in the tumor to investigate the influence of oxidative stress, through detection of TBARS in terms of MDA (Pompella et al., 1987; Kudryavtseva et al., 2016). After treatment with F2, there was a significant increase in MDA, thus treatment induced lipoperoxidation in the tumor (Figure 11C). 

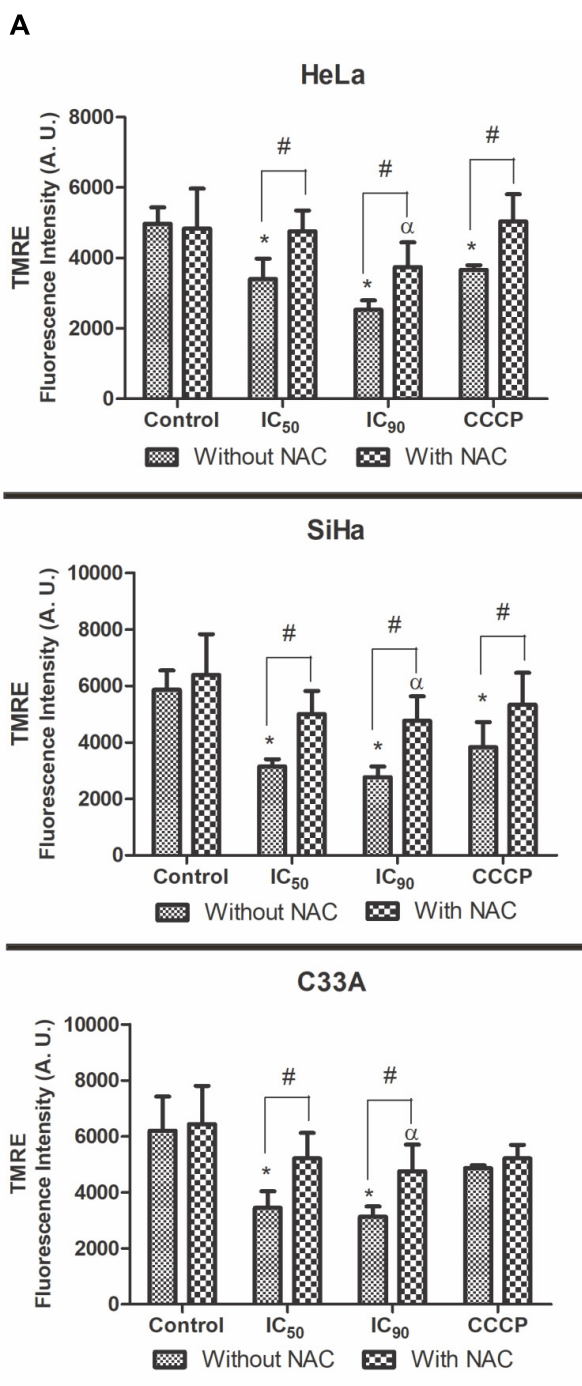
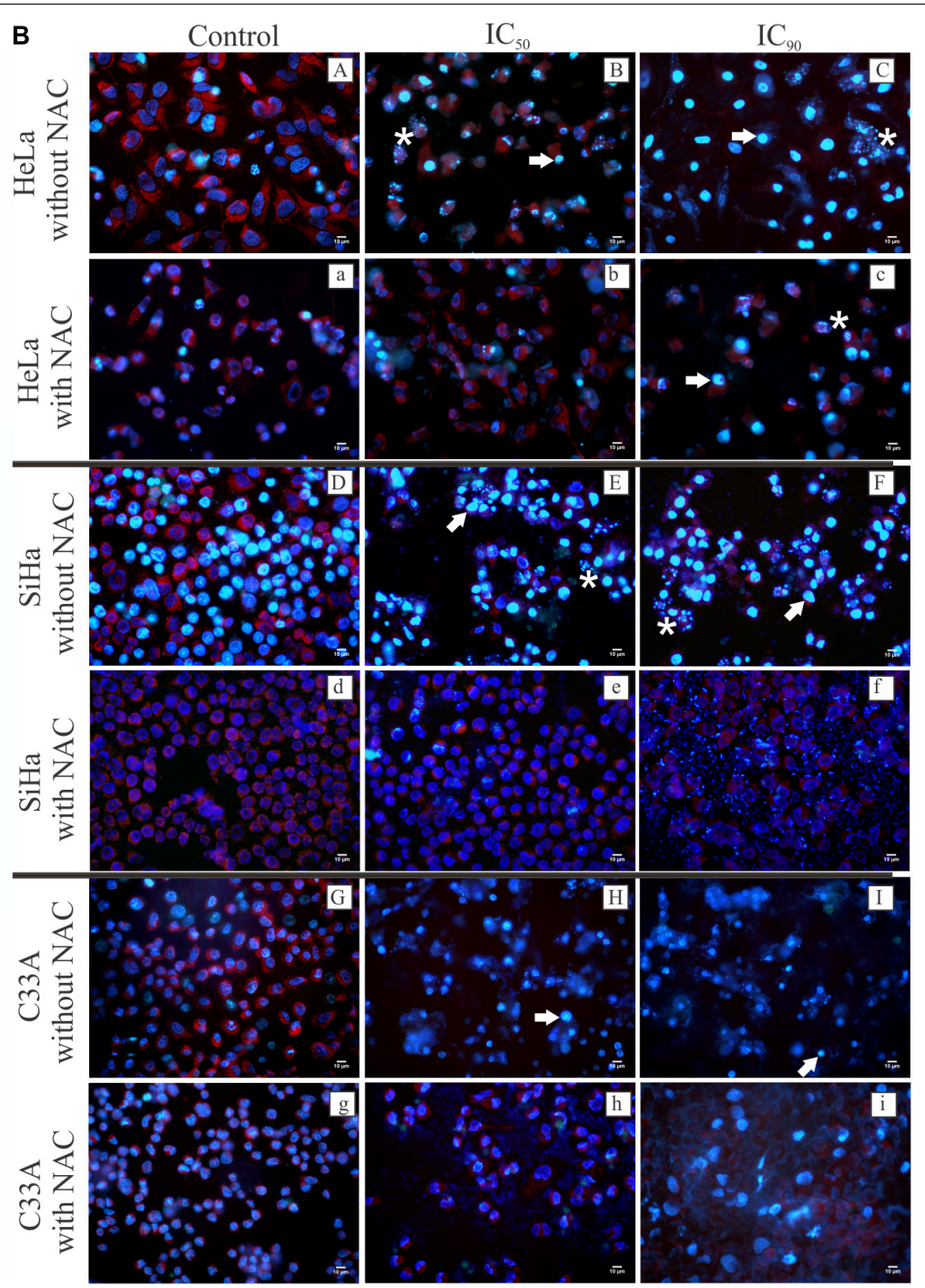

C

HeLa
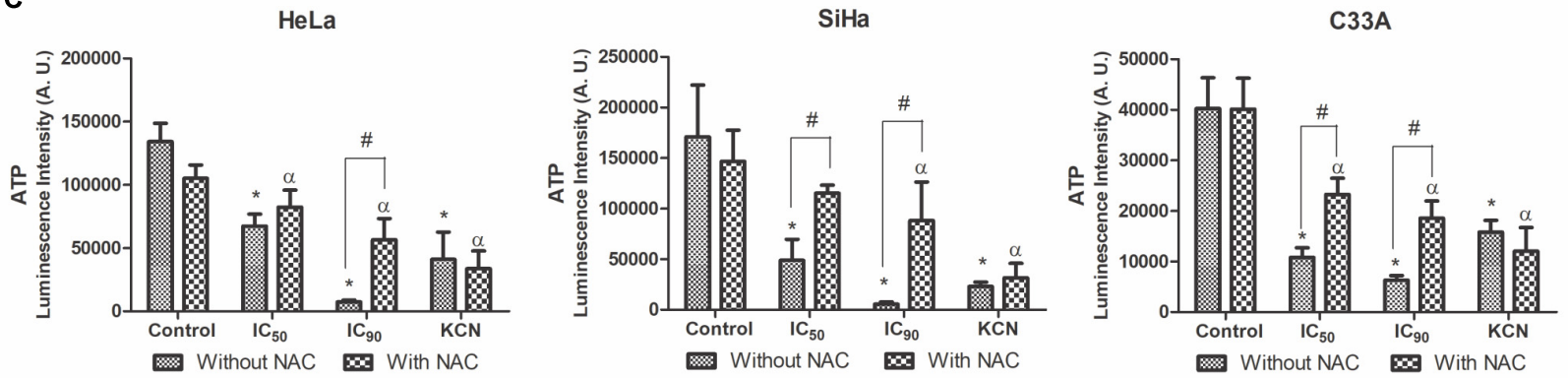

FIGURE 6 | (A) Mitochondrial membrane potential $(\Delta \Psi \mathrm{m})$ quantification by the marker TMRE. (B) Fluorescence microscopy analysis of $\Delta \Psi \mathrm{m}$ by the marker TMRE (red fluorescence) and DNA integrity analysis by the marker Hoechst 33342 (blue fluorescence), showing DNA fragmentation (white asterisk) and chromatin condensation (white arrow). (C) Intracellular ATP levels were determined by Cell Titer-GLO reagent. Cervical cancer cell lines (HeLa, SiHa, and C33A cells) were treated with the proanthocyanidin polymer-rich fraction $\left(\mathrm{IC}_{50}\right.$ or $\left.\mathrm{IC}_{90}\right)$ for $24 \mathrm{~h}$. The cells were pre-incubated with or without $\mathrm{N}$-acetylcysteine $(5 \mathrm{mM})$ for $2 \mathrm{~h}$ before $\mathrm{F} 2$ treatment. The positive control was CCCP $(100 \mu \mathrm{M})$ and $\mathrm{KCN}(1000 \mu \mathrm{M})$. The data are expressed as the mean \pm SD of three experiments that were performed in triplicate. ${ }^{*} p \leq 0.05$, significant difference from control (untreated cells; one-way ANOVA followed by Dunnett's post hoc test); ${ }^{\alpha} p \leq 0.05$, significant difference from control + NAC (one-way ANOVA followed by Dunnett's post hoc test); ${ }^{*} p \leq 0.05$, significant difference between treatment with and without NAC (two-way ANOVA followed by Bonferroni post hoc test). 


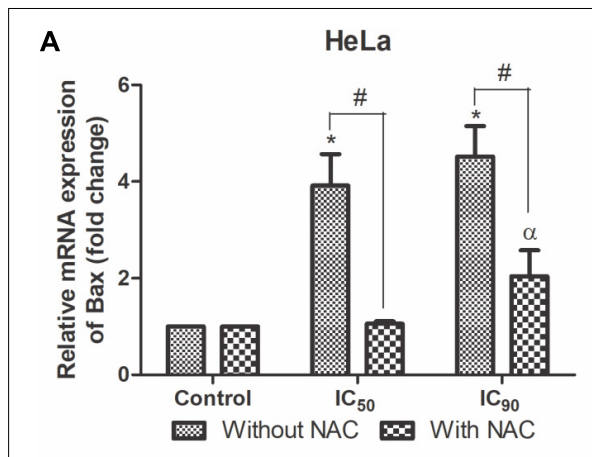

B

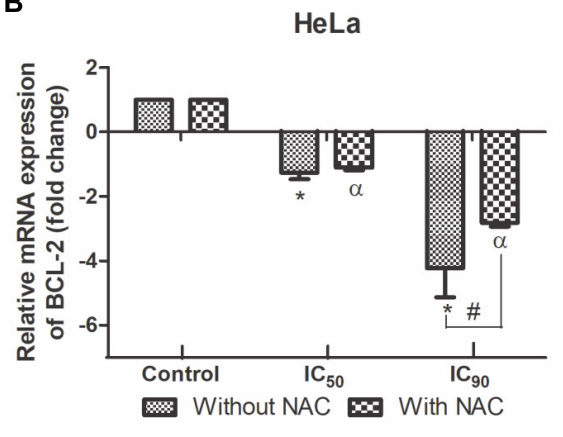

C

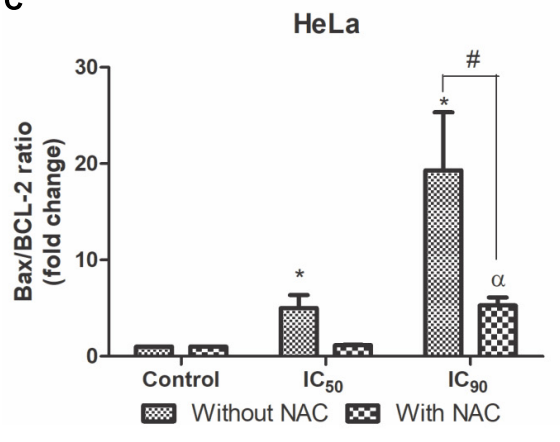

$\mathrm{SiHa}$

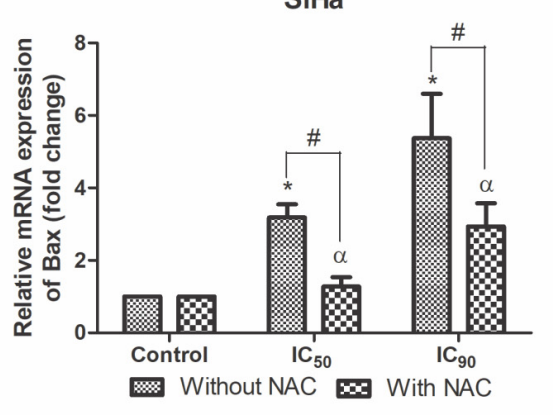

SiHa

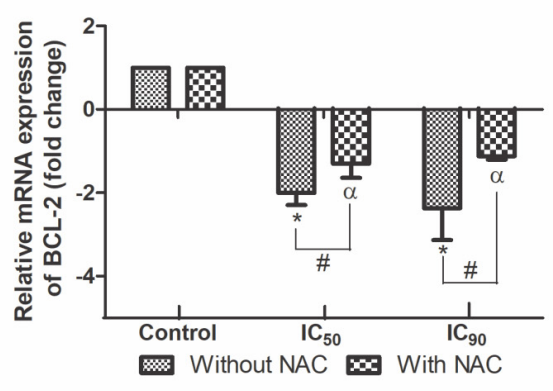

SiHa

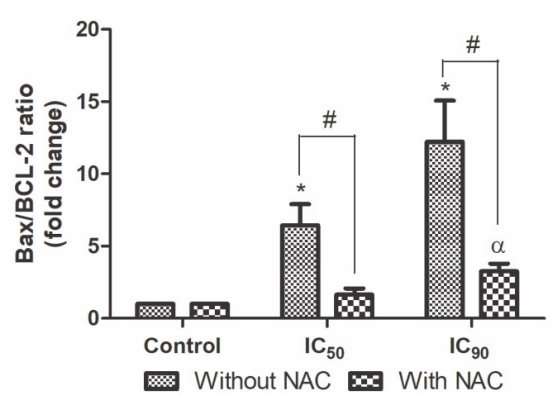

C33A

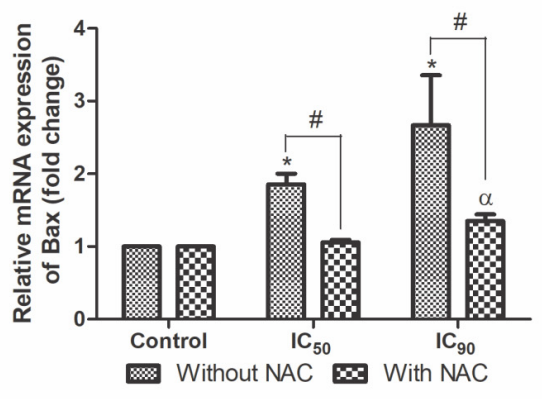

C33A

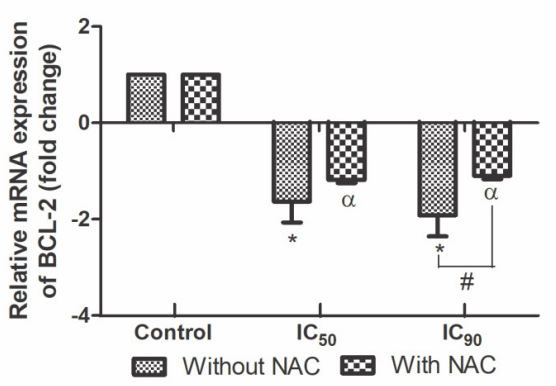

FIGURE 7 | Real-time PCR of relative mRNA expression levels of Bax (A), BCL-2 (B) and Bax/BCL-2 ratio (C) in cervical cancer cell lines (HeLa, SiHa, and C33A cells) treated with the proanthocyanidin polymer-rich fraction $\left(I_{50}\right.$ or $\left.I_{90}\right)$ for $12 \mathrm{~h}$. The cells were pre-incubated with or without $\mathrm{N}$-acetylcysteine $(5 \mathrm{mM})$ for $2 \mathrm{~h}$ before F2 treatment. The data are expressed as the mean \pm SD of two experiments that were performed in duplicate. ${ }^{*} p \leq 0.05$, significant difference from control (untreated cells; one-way ANOVA followed by Dunnett's post hoc test); ${ }^{\alpha} p \leq 0.05$, significant difference from control + NAC (one-way ANOVA followed by Dunnett's post hoc test); ${ }^{\#} p \leq 0.05$, significant difference between treatment with and without NAC (two-way ANOVA followed by Bonferroni post hoc test).

\section{DISCUSSION}

The proanthocyanidin polymer-rich fraction of S. adstringens (F2) time- and dose-dependently reduced the viability of HeLa (HPV18-positive), SiHa (HPV16-positive), and C33A (HPVnegative) cell lines. In vitro, $\mathrm{F} 2$ treatment $\left(\mathrm{IC}_{50}\right)$ induced intense oxidative stress and mitochondrial damage that were sufficient to trigger mitochondria-dependent apoptosis. Treatment with the high concentration of $\mathrm{F} 2$ ( $\mathrm{IC}_{90}$ ) resulted in progression to late apoptosis/necrosis. The synthetic antioxidant $\mathrm{N}$-acetylcysteine significantly suppressed oxidative stress. In the murine Ehrlich solid tumor model, F2 exerted potent in vivo anticancer activity.

Polyphenols, such as proanthocyanidins, are widely investigated as cancer therapies (Nandakumar et al., 2008;
Zhou et al., 2016). Here, proanthocyanidin polymer-rich fraction of S. adstringens (F2) treatment time- and dose-dependently reduced the viability of HeLa, SiHa, and C33A cells. Grape seed proanthocyanidins treatment showed similar cytotoxic activity in cervical cancer cells (Chen et al., 2014). It should be highlighted that F2 was significantly less toxic for HaCaT cells than cervical cancer cells. Furthermore, the F2 cytotoxic concentration for $50 \%$ cells $\left(\mathrm{CC}_{50}\right)$ was the same 125,150 , and $>1,000 \mu \mathrm{g} / \mathrm{ml}$ for murine macrophages (J774G8 cells), green monkey kidney (Vero cells) and red blood cells, respectively (Ishida et al., 2006).

Cancer cell migration and invasion are the first steps of metastasis (Clark and Vignjevic, 2015). In the wound healing assay with $\mathrm{HeLa}$, SiHa, and C33A cells, F2 treatment significantly inhibited cancer cell migration. The morphology of all three cell 

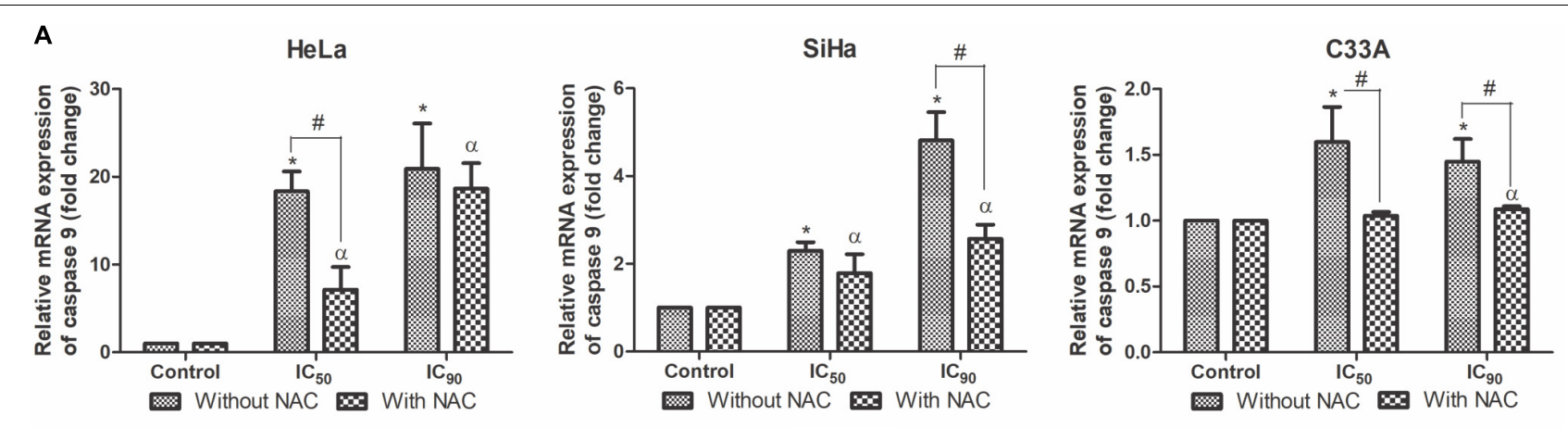

B

HeLa
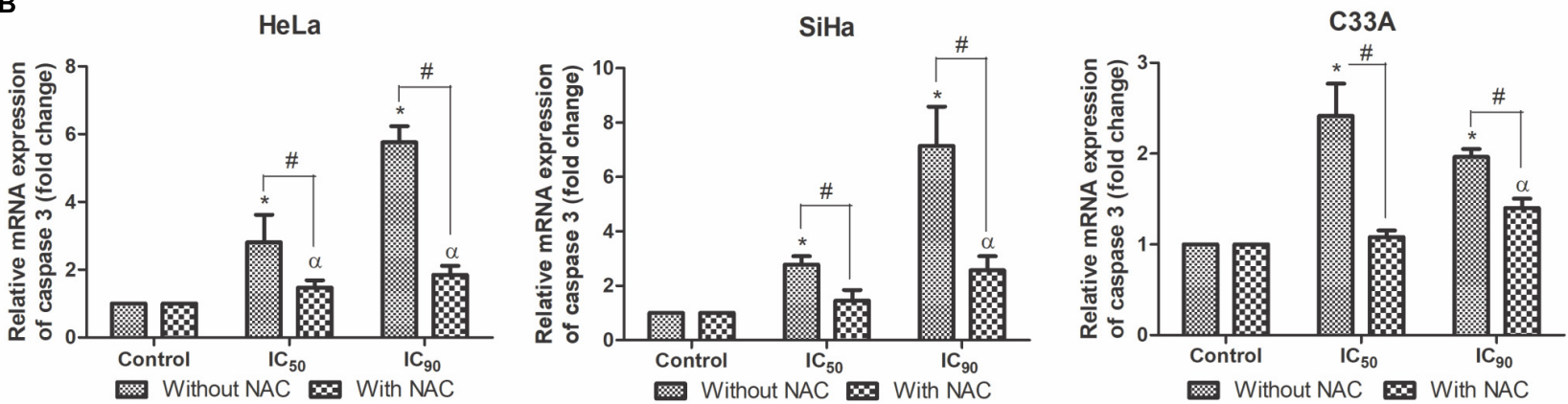

FIGURE 8 | Real-time PCR of relative mRNA expression levels of caspase 9 (A) and caspase 3 (B) in cervical cancer cell lines (HeLa, SiHa, and C33A cells) treated with the proanthocyanidin polymer-rich fraction $\left(\mathrm{IC}_{50}\right.$ or $\left.\mathrm{IC}_{90}\right)$ for $12 \mathrm{~h}$. The cells were pre-incubated with or without $\mathrm{N}$-acetylcysteine $(5 \mathrm{mM})$ for $2 \mathrm{~h}$ before $\mathrm{F} 2$ treatment. The data are expressed as the mean $\pm \mathrm{SD}$ of two experiments that were performed in duplicate. ${ }^{*} p \leq 0.05$, significant difference from control (untreated cells; one-way ANOVA followed by Dunnett's post hoc test); ${ }^{\alpha} p \leq 0.05$, significant difference from control + NAC (one-way ANOVA followed by Dunnett's post hoc test); ${ }^{~} p \leq 0.05$, significant difference between treatment with and without NAC (two-way ANOVA followed by Bonferroni post hoc test).

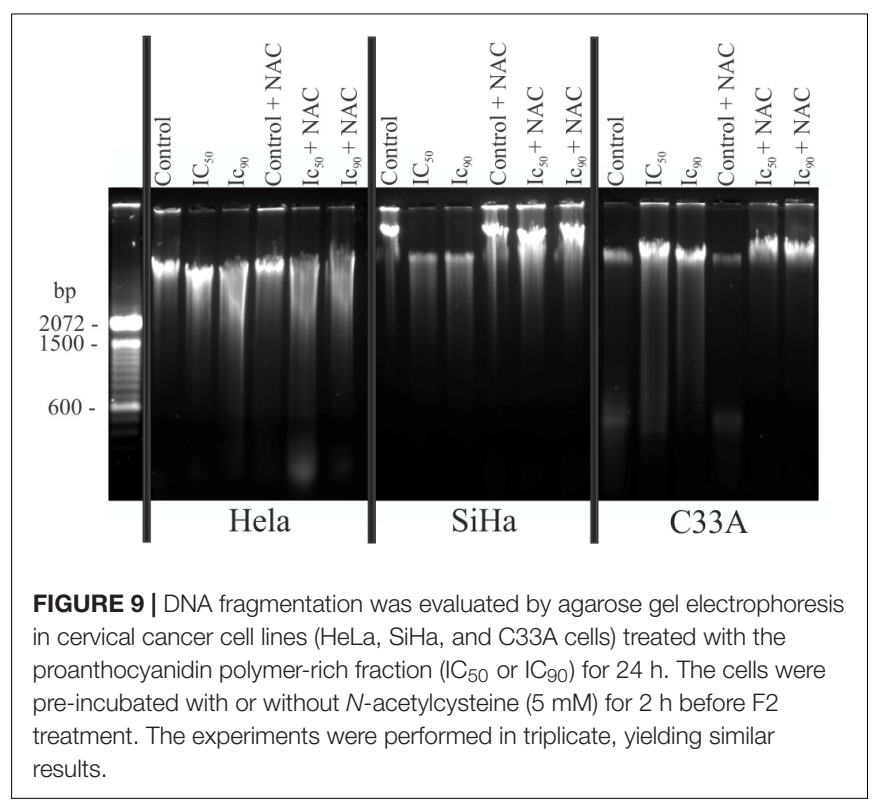

lines showed intense alterations, such as the irregularity of shape, cellular detachment, and a bright circle around the nucleus.

Morphological analysis by transmission electron microscopy is considered the "gold standard" for understanding and classifying cell death (Vanden Berghe et al., 2013). Generally, in apoptosis, cells undergo fragmentation and condensation of the nucleus and the swelling of organelles, such as mitochondria. Apoptotic cells may undergo a late process of secondary necrosis, characterized by cell membrane disruption (Wong, 2011). In addition to TEM, OA/PI double staining was performed to classify cell death. HeLa and SiHa cells treated with F2 $\left(\mathrm{IC}_{50}\right)$ exhibited intense nuclear and mitochondrial changes and increase in the percentage of early apoptotic cells in the AO/PI assay. $\mathrm{HeLa}$ and $\mathrm{SiHa}$ cells treated with the $\mathrm{IC}_{90}$ also resulted in cell membrane disruption, which is characteristic of late apoptosis and secondary necrosis that were also observed in the $\mathrm{AO} / \mathrm{PI}$ assay. In C33A cells, all of the aforementioned changes in TEM and AO/PI double staining were observed at both concentrations of F2, indicating late apoptosis and secondary necrosis.

However, the synthetic antioxidant $N$-acetylcysteine preserved organelle ultrastructure and increased cell viability in TEM and in OA/PI double staining, respectively. NAC scavenges ROS and increases GSH synthesis, likely increasing viable cells (Zafarullah et al., 2003). For this reason, we evaluated the oxidative stress in all three cell lines.

Oxidative stress is defined as the lack of equilibrium between ROS and endogenous antioxidant species (Sosa et al., 2013). ROS are reactive and short-lived molecules that contains unpaired electrons, as hydroxyl $\left(\mathrm{OH}^{\bullet}\right)$ and non-radical ROS, as hydrogen peroxide $\left(\mathrm{H}_{2} \mathrm{O}_{2}\right)$ (Moloney and Cotter, 2017). Endogenous antioxidants include the thiol-based intracellular antioxidant 

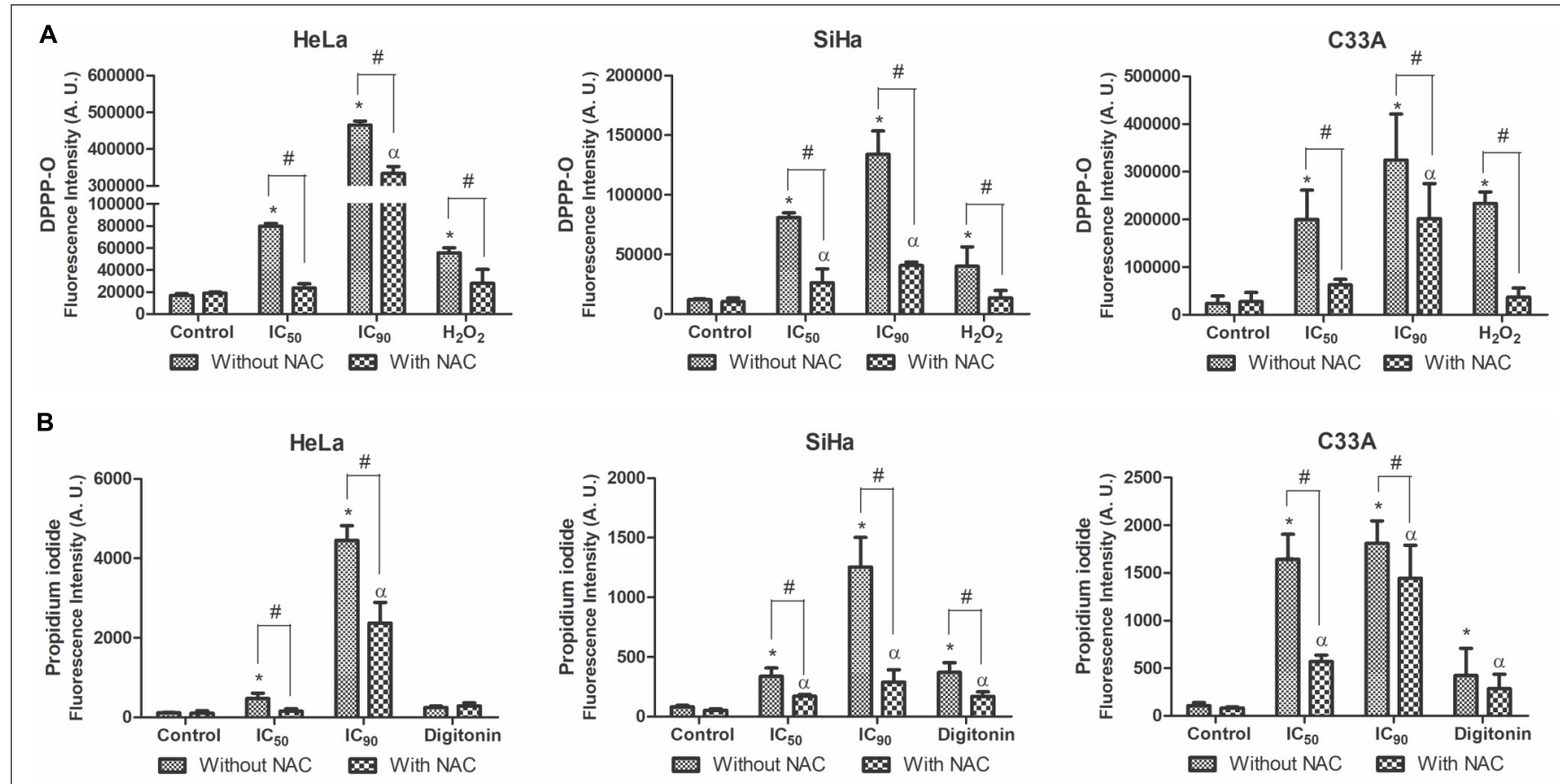

FIGURE 10 | Lipoperoxidation (A) and cell membrane integrity (B) in cervical cancer cell lines (HeLa, SiHa, and C33A cells) treated with the proanthocyanidin polymer-rich fraction $\left(\mathrm{IC}_{50}\right.$ or $\left.\mathrm{IC}_{90}\right)$ for $24 \mathrm{~h}$. The cells were pre-incubated with or without $\mathrm{N}$-acetylcysteine $(5 \mathrm{mM})$ for $2 \mathrm{~h}$ before F2 treatment. The positive control was $\mathrm{H}_{2} \mathrm{O}_{2}(200 \mu \mathrm{M})$ and digitonin $(80 \mu \mathrm{M})$. The data are expressed as the mean $\pm \mathrm{SD}$ of three experiments performed in triplicate. ${ }^{*} p \leq 0.05$, significant difference from control (untreated cells; one-way ANOVA followed by Dunnett's post hoc test); ${ }^{\alpha} p \leq 0.05$, significant difference from control + NAC (one-way ANOVA followed by Dunnett's post hoc test); ${ }^{n} p \leq 0.05$, significant difference between treatment with and without NAC (two-way ANOVA followed by Bonferroni post hoc test).
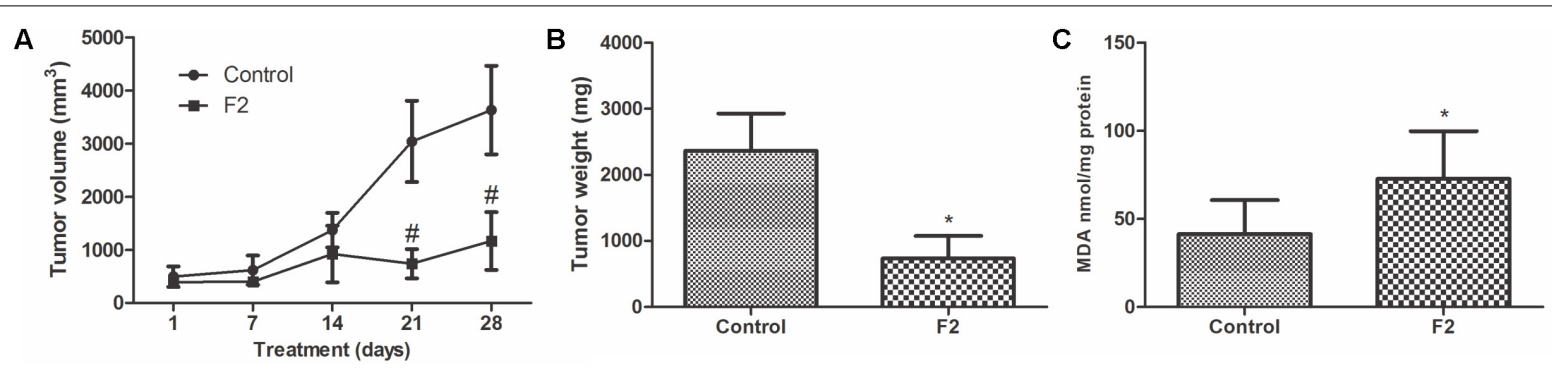

FIGURE 11 | In vivo anticancer activity of proanthocyanidin polymer-rich fraction (F2) in BALB/c mice with Ehrlich solid tumors. Treatment included control group (untreated control) and F2 group (150 mg/kg/day). Both treatments were administered orally and daily for 28 days. (A) The dimensions of Ehrlich solid tumors were recorded weekly by calculating the tumor volume. (B) Ehrlich solid tumors were weighted after the animal were euthanized. (C) Lipid peroxidation by TBARS in terms of MDA. The data are expressed as the mean $\pm \mathrm{SD}\left(n=5 /\right.$ group). ${ }^{*} p \leq 0.05$, significant difference between control and F2 (Mann-Whitney test); ${ }^{\#} p \leq 0.05$, significant difference between control and F2 (two-way ANOVA followed by Bonferroni post hoc test).

glutathione (GSH), the most abundant ROS scavenging agent in the cell (Dickinson and Forman, 2002; Sosa et al., 2013). Cancer cells are distinguished by high levels of oxidative stress. Thus, ROS accumulation in cancer cells is more harmful than in normal cells. Therefore, an increase in oxidative stress induces death preferentially in cancer cells (Gorrini et al., 2013; Panieri and Santoro, 2016).

HeLa, SiHa, and C33A cells treated with F2 exhibited a significant dose-dependent increase in ROS generation and a significant decrease in reduced thiols levels, indicating that intense oxidative stress triggered cell death. This suggests that the pro-oxidant properties of $\mathrm{F} 2$ promotes cell death mechanisms in oxidative stress-sensitive cancers, such as cervical cancer. Similarly, other polyphenols can also induce oxidative stress (Mileo and Miccadei, 2016; Mao et al., 2017). Furthermore, preincubation with antioxidant NAC reverted oxidative stress, confirming that this effect mediated cancer cell death. NAC preincubation also prevents oxidative stress in other cancer cells (Chang et al., 2017; Shiau et al., 2017).

Mitochondria are major sources of intracellular ROS, and a disproportional increase in ROS production, as in oxidative stress, can result in mitochondrial dysfunction (Redza-Dutordoir and Averill-Bates, 2016). Disturbances in membrane integrity can result in mitochondria-mediated apoptosis, usually manifested 
by $\Delta \Psi \mathrm{m}$ depolarization and a decrease in ATP levels (Sinha et al., 2013). In the present study, all three cell lines treated with F2 exhibited significant dose-dependent decrease in $\Delta \Psi \mathrm{m}$ and intracellular ATP levels. However, lower depolarization of $\Delta \Psi \mathrm{m}$ and higher levels of intracellular ATP were observed in cells preincubated with NAC. This indicates that the synthetic antioxidant protected mitochondrion integrity from ROS-induced damage in cells treated with the $\mathrm{IC}_{50}$ of $\mathrm{F} 2$. Reactive oxygen species production was incompletely scavenged by NAC when the cells treated with the $\mathrm{IC}_{90}$, revealed by TEM micrographs. S. adstringens induced mitochondrial damage in isolated rat liver mitochondria, apparently due to uncoupling of oxidative phosphorylation, inhibition of mitochondrial electron transport and inhibition of ATP-synthase (Rebecca et al., 2003).

Considering the mitochondrial depolarization, we evaluated the mitochondrial membrane integrity. Mitochondrial depolarization results from a pore-forming mechanism controlled by the BCL-2 family, especially the pro-apoptotic Bax and anti-apoptotic BCL-2 (Sinha et al., 2013). An increase in Bax protein levels leads to the formation of multimeric pores in the mitochondrial membrane, resulting in the release of proapoptotic factors into the cytosol. BCL-2 protein prevents this release, thus protecting the cell from apoptosis (Hata et al., 2015). The Bax/BCL-2 ratio is critical for the induction of apoptosis, and a significant increase in the Bax/BCL-2 ratio was observed after F2 treatment. Cells pre-incubated with NAC resulted in a decrease in the Bax/BCL-2 ratio, reducing the susceptibility of cells to apoptosis.

In the treatment with F2, mitochondrial damage associated with the increase of Bax/BCL-2 ratio likely induced mitochondrial-dependent pathway of apoptosis. In this pathway, pro-apoptotic factors are released into the cytosol, including cytochrome $c$, which binds to apoptotic protease activating factor (Apaf-1) and pro-caspase 9 to form the apoptosome that activates caspase 3 , resulting in cellular damage, such as DNA fragmentation (Ashkenazi et al., 2017). HeLa, SiHa, and C33A cells treated with F2 exhibited a dose-dependent upregulation of caspase 9 and caspase 3 mRNA expression levels. All three cell lines pre-incubated with NAC exhibited equal or less caspase 9 and caspase 3 mRNA expression levels compared with cells treated only with F2, thus confirming the protective effect of $\mathrm{N}$-acetylcysteine due to oxidative stress intensity reduction.

The increase of caspase 3 results in DNA fragmentation, which is a hallmark of apoptosis (Prokhorova et al., 2015). All three cell lines underwent DNA fragmentation, revealed by agarose gel electrophoresis and the marker Hoechst 33342, after treatment with F2, confirming an apoptotic process. DNA fragmentation also was observed in human breast cancer cells treated with S. adstringens leaf fraction (Sabino et al., 2017).

Furthermore, oxidative stress induces lipoperoxidation, specifically through lipid hydroperoxides that affect lipidcontaining structures (Kudryavtseva et al., 2016). F2 treatment significantly increased lipoperoxidation in all three cell lines. The excess accumulation of lipid hydroperoxides under depletion of reduced thiol levels and intracellular ATP can promote cell membrane disruption, resulting in cells with typical necrosis morphology (Higuchi, 2004; Ryter et al., 2007;
Rasola and Bernardi, 2011). Thus, an intense cell membrane disruption was observed after treatment with the $\mathrm{IC}_{50}$ of $\mathrm{F} 2$ in $\mathrm{C} 33 \mathrm{~A}$ cells and treatment with the $\mathrm{IC}_{90}$ in all three cell lines, as revealed by transmission electron microscopy and OA/PI double staining. Lipoperoxidation was lower in cells preincubated with NAC, as well as the damage in cell membrane. These results suggest that the ROS scavenger protected all the cell lines by reducing oxidative stress intensity.

HeLa and SiHa cells contain integrated HPV18 and HPV16 DNA, respectively (Ding et al., 2007). In these cells, F2 treatment induced intense oxidative stress and mitochondrial damage, and cell membrane disruption was observed at the high concentration $\left(\mathrm{IC}_{90}\right)$. C33A cells are HPV-negative and contain mutant p53 (Ding et al., 2007). In C33A cells, in addition to oxidative stress, notable cell membrane disruption was found with both treatments. The different cellular responses are likely attributable to different basal levels of ROS and antioxidant species in each cell line (Filippova et al., 2014).

In vivo tumor models are essential for the evaluation of possible chemotherapies (Jung, 2014). Ehrlich solid tumors provide an efficient way to investigate chemotherapeutic agents (Noaman et al., 2008; Biswas et al., 2016; Srivastava et al., 2016). This tumor is formed through the subcutaneous inoculation of Ehrlich ascites carcinoma cells, a breast adenocarcinoma (Ozaslan et al., 2013). Based on promising in vitro results, F2 was evaluated in a murine Ehrlich solid tumor model. The administration of $150 \mathrm{mg} / \mathrm{kg} /$ day F2 in mice significantly reduced tumor volume and tumor weight. Synergism between vanillin and doxorubicin showed similar results in Ehrlich solid tumors (Elsherbiny et al., 2016). In vitro, F2 induced oxidative stress in cancer cells, resulting in intense lipoperoxidation. Similarly, there was also lipoperoxidation increase in tumors treated with $\mathrm{F} 2$, indicating that $\mathrm{F} 2$ also induces oxidative stress in the in vivo model.

Previous work has shown that polyphenols may trigger DNA damage and lipoperoxidation due to ROS generation (León-González et al., 2015). Furthermore, suppression of endogenous antioxidants leads to cancer cells sensitization to chemo- and radiotherapy (Sznarkowska et al., 2017). Considering that pro-oxidant activity of F2 induced oxidative stress, proanthocyanidins could potentially lead to a new group of natural chemotherapeutic agents, either used alone or in combination therapy to reduce drug resistance. Thus, natural plant-based polyphenolic compounds are promising as future cancer chemotherapeutic agents (León-González et al., 2015; Redondo-Blanco et al., 2017).

\section{CONCLUSION}

The proanthocyanidin polymer-rich fraction of $S$. adstringens time- and dose-dependently reduced cell viability and the migration of the cervical cancer cell lines HeLa (HPV-18 positive), SiHa (HPV-16 positive), and C33A (HPV-negative). In HeLa and SiHa cells, F2 treatment $\left(\mathrm{IC}_{50}\right)$ induced intense oxidative stress and mitochondrial damage sufficient to trigger mitochondria-dependent apoptosis. Moreover, cell membrane 
disruption was observed in $\mathrm{C} 33 \mathrm{~A}$ cells $\left(\mathrm{IC}_{50}\right.$ and $\left.\mathrm{IC}_{90}\right)$ and $\mathrm{HeLa}$ and $\mathrm{SiHa}$ cells ( $\mathrm{IC}_{90}$ ), indicating progression to late apoptosis/necrosis. The inhibition of ROS production by the synthetic antioxidant NAC significantly suppressed oxidative stress in all three cell lines. Anticancer activity in vivo of F2 in the Ehrlich solid tumor showed significantly reduced tumor volume and weight. Similar to the in vitro results, F2 significantly increased lipoperoxidation, indicating that F2 also induces oxidative stress in the in vivo model. In conclusion, the proanthocyanidin polymer-rich fraction of $S$. adstringens may be a potential chemotherapeutic candidate for cancer treatment.

\section{AUTHOR CONTRIBUTIONS}

VK conception, design and execution of the experimental studies, analysis and interpretation of the results, draft and

\section{REFERENCES}

Albuquerque, U. P., Monteiro, J. M., Ramos, M. A., and de Amorim, E. L. C. (2007). Medicinal and magic plants from a public market in northeastern Brazil. J. Ethnopharmacol. 110, 76-91. doi: 10.1016/j.jep.2006.09.010

Ashkenazi, A., Fairbrother, W. J., Leverson, J. D., and Souers, A. J. (2017). From basic apoptosis discoveries to advanced selective BCL-2 family inhibitors. Nat. Rev. Drug Discov. 16, 273-284. doi: 10.1038/nrd. 2016.253

Biswas, S., Pardeshi, R., Reddy, N. D., Shoja, M. H., Nayak, P. G., Setty, M. M., et al. (2016). Bulbophyllum sterile petroleum ether fraction induces apoptosis in vitro and ameliorates tumor progression in vivo. Biomed. Pharmacother. 84, 1419-1427. doi: 10.1016/j.biopha.2016.10.005

Chang, H.-W., Li, R.-N., Wang, H.-R., Liu, J.-R., Tang, J.-Y., Huang, H.-W., et al. (2017). Withaferin a induces oxidative stress-mediated apoptosis and DNA damage in oral cancer cells. Front. Physiol. 8:634. doi: 10.3389/fphys.2017. 00634

Chen, Q., Liu, X. F., and Zheng, P. S. (2014). Grape seed proanthocyanidins (GSPs) inhibit the growth of cervical cancer by inducing apoptosis mediated by the mitochondrial pathway. PLoS One 9:e107045. doi: 10.1371/journal.pone. 0107045

Chen, W., Zhao, Y., Seefeldt, T., and Guan, X. (2008). Determination of thiols and disulfides via HPLC quantification of 5-thio-2-nitrobenzoic acid. J. Pharm. Biomed. Anal. 48, 1375-1380. doi: 10.1016/j.jpba.2008.08.033

Clark, A. G., and Vignjevic, D. M. (2015). Modes of cancer cell invasion and the role of the microenvironment. Curr. Opin. Cell Biol. 36, 13-22. doi: 10.1016/j. ceb.2015.06.004

Costa, M. A., de Mello, J. C. P., Kaneshima, E. N., Ueda-Nakamura, T., Dias Filho, B. P., Audi, E. A., et al. (2013). Acute and chronic toxicity of an aqueous fraction of the stem bark of Stryphnodendron adstringens (Barbatimão) in rodents. Evid. Based Complement. Altern. Med. 2013:841580. doi: 10.1155/2013/ 841580

Costa, M. A., Ishida, K., Kaplum, V., Koslyk, É. D. A., de Mello, J. C. P., Ueda-Nakamura, T., et al. (2010). Safety evaluation of proanthocyanidin polymer-rich fraction obtained from stem bark of Stryphnodendron adstringens (BARBATIMO) for use as a pharmacological agent. Regul. Toxicol. Pharmacol. 58, 330-335. doi: 10.1016/j.yrtph.2010.07.006

Crosbie, E. J., Einstein, M. H., Franceschi, S., and Kitchener, H. C. (2013). Human papillomavirus and cervical cancer. Lancet 382, 889-899. doi: 10.1016/S01406736(13)60022-7

de Freitas, A. L. D., Kaplum, V., Rossi, D. C. P., da Silva, L. B. R., Melhem, M. S. C., Taborda, C. P., et al. (2018). Proanthocyanidin polymeric tannins from Stryphnodendron adstringens are effective against Candida spp. isolates and for vaginal candidiasis treatment. J. Ethnopharmacol. 216, 184-190. doi: 10.1016/j.jep.2018.01.008 writing of the manuscript. AR conception and execution of the experimental studies. MC, MF, TU-N, BD-F, SS, and JdM conception and design of the study, critical review and correction of the manuscript. CN coordination of all stages of the work, conception, design and draft the study, critical review and correction of the manuscript.

\section{FUNDING}

This work was supported by Conselho Nacional de Desenvolvimento Científico e Tecnológico (CNPq) [401100/2013-8], Coordenação de Aperfeiçoamento de Pessoal de Nível Superior (CAPES), Financiadora de Estudos e Projetos (FINEP), Pronex/Fundação Araucária, COMCAP Complexo de Centrais de Apoio a Pesquisa - UEM, and Programa de Pós-Graduação em Ciências Farmacêuticas.

de Mello, J. C. P., Petereit, F., and Nahrstedt, A. (1996a). Flavan-3-ols and prodelphinidins from Stryphnodendron adstringens. Phytochemistry 41, 807-813. doi: 10.1016/0031-9422(95)00686-9

de Mello, J. C. P., Petereit, F., and Nahrstedt, A. (1996b). Prorobinetinidins from Stryphnodendron adstringens. Phytochemistry 42, 857-862. doi: 10.1016/00319422(95)00953- 1

de Mello, J. C. P., Petereit, F., and Nahrstedt, A. (1999). A dimeric proanthocyanidin from Stryphnodendron adstringens. Phytochemistry 51, 1105-1107. doi: 10.1016/S0031-9422(98)00715-8

Debski, D., Smulik, R., Zielonka, J., Michałowski, B., Jakubowska, M., Debowska, K., et al. (2016). Mechanism of oxidative conversion of Amplex ${ }^{\circledR}$ Red to resorufin: pulse radiolysis and enzymatic studies. Free Radic. Biol. Med. 95, 323-332. doi: 10.1016/j.freeradbiomed.2016.03.027

Dickinson, D. A., and Forman, H. J. (2002). Cellular glutathione and thiols metabolism. Biochem. Pharmacol. 64, 1019-1026. doi: 10.1016/S0006-2952(02) 01172-3

Ding, B., Chi, S. G., Kim, S. H., Kang, S., Cho, J. H., Kim, D. S., et al. (2007). Role of p53 in antioxidant defense of HPV-positive cervical carcinoma cells following H2O2 exposure. J. Cell Sci. 120, 2284-2294. doi: 10.1242/jcs. 002345

Elsherbiny, N. M., Younis, N. N., Shaheen, M. A., and Elseweidy, M. M. (2016). The synergistic effect between vanillin and doxorubicin in ehrlich ascites carcinoma solid tumor and MCF-7 human breast cancer cell line. Pathol. Res. Pract. 212, 767-777. doi: 10.1016/j.prp.2016.06.004

Filippova, M., Filippov, V., Williams, V. M., Zhang, K., Kokoza, A., Bashkirova, S., et al. (2014). Cellular levels of oxidative stress affect the response of cervical cancer cells to chemotherapeutic agents. Biomed Res. Int. 2014:574659. doi: $10.1155 / 2014 / 574659$

Fulda, S., Gorman, A. M., Hori, O., and Samali, A. (2010). Cellular stress responses: cell survival and cell death. Int. J. Cell Biol. 2010:214074. doi: 10.1155/2010/ 214074

Gorrini, C., Harris, I. S., and Mak, T. W. (2013). Modulation of oxidative stress as an anticancer strategy. Nat. Rev. Drug Discov. 12, 931-947. doi: 10.1038/ $\operatorname{nrd} 4002$

Graham, S. V. (2017). The human papillomavirus replication cycle, and its links to cancer progression: a comprehensive review. Clin. Sci. 131, 2201-2221. doi: 10.1042/CS20160786

Hajrezaie, M., Paydar, M., Looi, C. Y., Moghadamtousi, S. Z., Hassandarvish, P., Salga, M. S., et al. (2015). Apoptotic effect of novel Schiff based $\mathrm{CdCl} 2(\mathrm{C} 14 \mathrm{H} 21 \mathrm{~N} 3 \mathrm{O} 2)$ complex is mediated via activation of the mitochondrial pathway in colon cancer cells. Sci. Rep. 5:9097. doi: 10.1038/srep 09097

Hata, A. N., Engelman, J. A., and Faber, A. C. (2015). The BCL2 family: key mediators of the apoptotic response to targeted anticancer therapeutics. Cancer Discov. 5, 475-487. doi: 10.1158/2159-8290.CD-15-0011 
Henriques, B. O., Corrêa, O., Azevedo, E. P. C., Pádua, R. M., Oliveira, V. L. S., de Oliveira, T. H. C., et al. (2016). In Vitro TNF- $\alpha$ inhibitory activity of Brazilian plants and anti-inflammatory effect of Stryphnodendron adstringens in an acute arthritis model. Evid. Based Complement. Altern. Med. 2016:9872598. doi: $10.1155 / 2016 / 9872598$

Higuchi, Y. (2004). Glutathione depletion-induced chromosomal DNA fragmentation associated with apoptosis and necrosis. J. Cell. Mol. Med. 8, 455-464. doi: 10.1016/j.ceca.2011.04.007

Holetz, F. B., Ueda-Nakamura, T., Dias Filho, B. P., De Mello, J. C. P., Morgado-Díaz, J. A., De Toledo, C. E. M., et al. (2005). Biological effects of extracts obtained from Stryphnodendron adstringens on Herpetomonas samuelpessoai. Mem. Inst. Oswaldo Cruz 100, 397-401. doi: 10.1590/S007402762005000400010

Ishida, K., de Mello, J. C. P., Cortez, D. A., Dias Filho, B. P., Ueda-Nakamura, T., and Nakamura, C. V. (2006). Influence of tannins from Stryphnodendron adstringens on growth and virulence factors of Candida albicans. J. Antimicrob. Chemother. 58, 942-949. doi: 10.1093/jac/dkl377

Jung, J. (2014). Human tumor xenograft models for preclinical assessment of anticancer drug development. Toxicol. Res. 30, 1-5. doi: 10.5487/TR.2014.30. 1.001

Kudryavtseva, A. V., Krasnov, G. S., Dmitriev, A. A., Alekseev, B. Y., Kardymon, O. L., Sadritdinova, A. F., et al. (2016). Mitochondrial dysfunction and oxidative stress in aging and cancer. Oncotarget 7, 44879-44905. doi: 10.18632/ oncotarget.9821

Larsen, B. D., and Sørensen, C. S. (2017). The caspase-activated DNase: apoptosis and beyond. FEBS J. 284, 1160-1170. doi: 10.1111/febs.13970

León-González, A. J., Auger, C., and Schini-Kerth, V. B. (2015). Pro-oxidant activity of polyphenols and its implication on cancer chemoprevention and chemotherapy. Biochem. Pharmacol. 98, 371-380. doi: 10.1016/j.bcp.2015. 07.017

Mao, X., Gu, C., Chen, D., Yu, B., and He, J. (2017). Oxidative stress-induced diseases and tea polyphenols. Oncotarget 8, 81649-81661. doi: 10.18632/ oncotarget. 20887

Martindale, J. L., and Holbrook, N. J. (2002). Cellular response to oxidative stress: signaling for suicide and survival. J. Cell. Physiol. 192, 1-15. doi: 10.1002/jcp. 10119

Mileo, A. M., and Miccadei, S. (2016). Polyphenols as modulator of oxidative stress in cancer disease: new therapeutic strategies. Oxid. Med. Cell. Longev. 2016, 1-17. doi: 10.1155/2016/6475624

Moloney, J. N., and Cotter, T. G. (2017). ROS signalling in the biology of cancer. Semin. Cell Dev. Biol. 80, 50-64. doi: 10.1016/j.semcdb.2017. 05.023

Nandakumar, V., Singh, T., and Katiyar, S. K. (2008). Multi-targeted prevention and therapy of cancer by proanthocyanidins. Cancer Lett. 269, 378-387. doi: 10.1016/j.canlet.2008.03.049

Ng, K.-B., Bustamam, A., Sukari, M. A., Abdelwahab, S. I., Mohan, S., Buckle, M. J. C., et al. (2013). Induction of selective cytotoxicity and apoptosis in human T4-lymphoblastoid cell line (CEMss) by boesenbergin a isolated from Boesenbergia rotunda rhizomes involves mitochondrial pathway, activation of caspase 3 and $\mathrm{G} 2 / \mathrm{M}$ phase cell cycle arrest. BMC Complement. Altern. Med. 13:41. doi: 10.1186/1472-6882$13-41$

Noaman, E., Badr El-Din, N. K., Bibars, M. A., Abou Mossallam, A. A., and Ghoneum, M. (2008). Antioxidant potential by arabinoxylan rice bran, MGN3/biobran, represents a mechanism for its oncostatic effect against murine solid Ehrlich carcinoma. Cancer Lett. 268, 348-359. doi: 10.1016/j.canlet.2008. 04.012

Okimoto, Y., Watanabe, A., Niki, E., Yamashita, T., and Noguchi, N. (2000). A novel fluorescent probe diphenyl-1-pyrenylphosphine to follow lipid peroxidation in cell membranes. FEBS Lett. 474, 137-140. doi: 10.1016/S00145793(00)01587-8

Ozaslan, M., Karagoz, I., Kilic, I., and Guldur, M. (2013). Ehrlich ascites carcinoma. Afr. J. Biotechnol. 10, 2375-2378. doi: 10.4314/ajb.v10i13

Panieri, E., and Santoro, M. M. (2016). ROS homeostasis and metabolism: a dangerous liason in cancer cells. Cell Death Dis. 7:e2253. doi: 10.1038/cddis. 2016.105

Pizzino, G., Irrera, N., Cucinotta, M., Pallio, G., Mannino, F., Arcoraci, V., et al. (2017). Oxidative stress: harms and benefits for human health. Oxid. Med. Cell. Longev. 2017:8416763. doi: 10.1155/2017/ 8416763

Pompella, A., Maellaro, E., Casini, A. F., Ferrali, M., Ciccoli, L., and Comporti, M. (1987). Measurement of lipid peroxidation in vivo: a comparison of different procedures. Lipids 22, 206-211. doi: 10.1007/BF025 37304

Prokhorova, E. A., Zamaraev, A. V., Kopeina, G. S., Zhivotovsky, B., and Lavrik, I. N. (2015). Role of the nucleus in apoptosis: signaling and execution. Cell. Mol. Life Sci. 72, 4593-4612. doi: 10.1007/s00018-015-2031-y

Rasola, A., and Bernardi, P. (2011). Mitochondrial permeability transition in Ca2++-dependent apoptosis and necrosis. Cell Calcium 50, 222-233. doi: 10.1016/j.ceca.2011.04.007

Rebecca, M. A., Ishii-Iwamoto, E. L., Kelmer-Bracht, A. M., Caparroz-Assef, S. M., Cuman, R. K. N., Pagadigorria, C. L. S., et al. (2003). Effect of Stryphnodendron adstringens (Barbatimão) on energy metabolism in the rat liver. Toxicol. Lett. 143, 55-63. doi: 10.1016/S0378-4274(03)00065-1

Redondo-Blanco, S., Fernández, J., Gutiérrez-del-Río, I., Villar, C. J., and Lombó, F. (2017). New insights toward colorectal cancer chemotherapy using natural bioactive compounds. Front. Pharmacol. 8:109. doi: 10.3389/fphar.2017. 00109

Redza-Dutordoir, M., and Averill-Bates, D. A. (2016). Activation of apoptosis signalling pathways by reactive oxygen species. Biochim. Biophys. Acta Mol. Cell Res. 1863, 2977-2992. doi: 10.1016/j.bbamcr.2016. 09.012

Ryter, S. W., Kim, H. P., Hoetzel, A., Park, J. W., Nakahira, K., Wang, X., et al. (2007). Mechanisms of cell death in oxidative stress. Antioxid. Redox Signal. 9, 49-89. doi: 10.1089/ars.2007.9.49

Sabino, A. P. L., Eustaquio, L. M. S., Miranda, A. C. F., Biojone, C., Mariosa, T. N., and Gouvea, C. M. C. P. (2017). Stryphnodendron adstringens ("Barbatimão") leaf fraction: chemical characterization, antioxidant activity, and cytotoxicity towards human breast cancer cell lines. Appl. Biochem. Biotechnol. 184, 1375-1389. doi: 10.1007/s12010-0172632-z

Schmittgen, T. D., and Livak, K. J. (2008). Analyzing real-time PCR data by the comparative CT method. Nat. Protoc. 3, 1101-1108. doi: 10.1038/nprot.2008.73

Shiau, J.-Y., Nakagawa-Goto, K., Lee, K.-H., and Shyur, L.-F. (2017). Phytoagent deoxyelephantopin derivative inhibits triple negative breast cancer cell activity by inducing oxidative stress-mediated paraptosislike cell death. Oncotarget 8, 56942-56958. doi: 10.18632/oncotarget. 18183

Sinha, K., Das, J., Pal, P. B., and Sil, P. C. (2013). Oxidative stress: the mitochondria-dependent and mitochondria-independent pathways of apoptosis. Arch. Toxicol. 87, 1157-1180. doi: 10.1007/s00204-0131034-4

Sosa, V., Moliné, T., Somoza, R., Paciucci, R., Kondoh, H., and LLeonart, M. E. (2013). Oxidative stress and cancer: an overview. Ageing Res. Rev. 12, 376-390. doi: 10.1016/j.arr.2012.10.004

Souza, R. P., Bonfim-Mendonça, P. S., Gimenes, F., Ratti, B. A., Kaplum, V., Bruschi, M. L., et al. (2017). Oxidative stress triggered by apigenin induces apoptosis in a comprehensive panel of human cervical cancerderived cell lines. Oxid. Med. Cell. Longev. 2017:1512745. doi: 10.1155/2017/ 1512745

Srivastava, S., Somasagara, R. R., Hegde, M., Nishana, M., Tadi, S. K., Srivastava, M., et al. (2016). Quercetin, a natural flavonoid interacts with DNA, arrests cell cycle and causes tumor regression by activating mitochondrial pathway of apoptosis. Sci. Rep. 6:24049. doi: 10.1038/srep24049

Sznarkowska, A., Kostecka, A., Meller, K., and Bielawski, K. P. (2017). Inhibition of cancer antioxidant defense by natural compounds. Oncotarget 8, 15996-16016. doi: 10.18632/oncotarget.13723

Vanden Berghe, T., Grootjans, S., Goossens, V., Dondelinger, Y., Krysko, D. V., Takahashi, N., et al. (2013). Determination of apoptotic and necrotic cell death in vitro and in vivo. Methods 61, 117-129. doi: 10.1016/j.ymeth.2013.02.011

Walsh, D. W. M., Siebenwirth, C., Greubel, C., Ilicic, K., Reindl, J., Girst, S., et al. (2017). Live cell imaging of mitochondria following targeted irradiation in situ reveals rapid and highly localized loss of membrane potential. Sci. Rep. 7:46684. doi: $10.1038 /$ srep46684

Winther, J. R., and Thorpe, C. (2014). Quantification of thiols and disulfides. Biochim. Biophys. Acta 1840, 838-846. doi: 10.1016/j.bbagen.2013.03.031 
Wong, R. S. (2011). Apoptosis in cancer: from pathogenesis to treatment. J. Exp. Clin. Cancer Res. 30:87. doi: 10.1186/1756-9966-30-87

Yazdani, M. (2015). Concerns in the application of fluorescent probes DCDHF-DA, DHR 123 and DHE to measure reactive oxygen species in vitro. Toxicol. Vitr. 30, 578-582. doi: 10.1016/j.tiv.2015.08.010

Zafarullah, M., Li, W. Q., Sylvester, J., and Ahmad, M. (2003). Molecular mechanisms of N -acetylcysteine actions. Cell. Mol. Life Sci. 60, 6-20. doi: $10.1007 / \mathrm{s} 000180300001$

Zhou, Y., Zheng, J., Li, Y., Xu, D. P., Li, S., Chen, Y. M., et al. (2016). Natural polyphenols for prevention and treatment of cancer. Nutrients 8:E515. doi: $10.3390 /$ nu 8080515
Conflict of Interest Statement: The authors declare that the research was conducted in the absence of any commercial or financial relationships that could be construed as a potential conflict of interest.

Copyright (๑) 2018 Kaplum, Ramos, Consolaro, Fernandez, Ueda-Nakamura, DiasFilho, Silva, de Mello and Nakamura. This is an open-access article distributed under the terms of the Creative Commons Attribution License (CC BY). The use, distribution or reproduction in other forums is permitted, provided the original author(s) and the copyright owner(s) are credited and that the original publication in this journal is cited, in accordance with accepted academic practice. No use, distribution or reproduction is permitted which does not comply with these terms. 